\title{
Diiron Complexes with a Bridging Functionalized Allylidene Ligand: Synthesis, Structural Aspects and Cytotoxicity
}

Silvia Schoch, ${ }^{a}$ Lucinda K. Batchelor, ${ }^{b}$ Tiziana Funaioli, ${ }^{a}$ Gianluca Ciancaleoni, ${ }^{a}$ Stefano Zacchini, ${ }^{c}$ Simona Braccini, ${ }^{a}$ Federica Chiellini, ${ }^{a}$ Tarita Biver, ${ }^{d}$ Guido Pampaloni, ${ }^{a}$ Paul J. Dyson, ${ }^{b}$ Fabio Marchetti $^{a{ }^{*}}$

${ }^{a}$ Dipartimento di Chimica e Chimica Industriale, Università di Pisa, Via G. Moruzzi 13, I-56124 Pisa, Italy.

${ }^{b}$ Institut des Sciences et Ingénierie Chimiques, Ecole Polytechnique Fédérale de Lausanne (EPFL), CH-1015 Lausanne, Switzerland.

c Dipartimento di Chimica Industriale “Toso Montanari”, Università di Bologna, Viale Risorgimento 4, I-40136 Bologna, Italy.

${ }^{d}$ Dipartimento di Farmacia, Università di Pisa, Via Bonanno 6, I-56126 Pisa, Italy.

\section{Corresponding Author}

*E-mail address: fabio.marchetti1974@unipi.it; webpage: http://people.unipi.it/fabio marchetti1974/. 


\begin{abstract}
Regio- and stereo-selective nucleophilic attack of cyanide (from $\mathrm{NBu}_{4} \mathrm{CN}$ ) to cationic diiron vinyliminium compounds $\left[\mathrm{Fe}_{2} \mathrm{Cp}_{2}(\mathrm{CO})(\mu-\mathrm{CO})\left\{\mu-\eta^{1}: \eta^{3}-\mathrm{C}\left(\mathrm{R}^{\prime}\right) \mathrm{C}\left(\mathrm{R}^{\prime \prime}\right) \mathrm{CNMe}_{2}\right\}\right] \mathrm{CF}_{3} \mathrm{SO}_{3}, \quad[\mathbf{1} \mathbf{a}-\mathbf{f}] \mathrm{CF}_{3} \mathrm{SO}_{3}$, affords nitrile-aminoallylidene derivatives, 2a-f, in good to excellent yield. The analogous reaction of $[\mathbf{1 g}] \mathrm{CF}_{3} \mathrm{SO}_{3}$, comprising two different $\mathrm{N}$-substituents, gives $4(63 \%)$ as a mixture of two stereoisomers. The new products $[\mathbf{1 g}] \mathrm{CF}_{3} \mathrm{SO}_{3}, \mathbf{2 a - f}$ and $\mathbf{4}$ were characterized by IR and NMR spectroscopy, and in a number of cases by IR-spectroelectrochemistry and single crystal X-ray diffraction. The allylidene complexes are air-stable and robust in aqueous solution, however, in general they undergo oxidation within a biologically relevant range of potentials. DFT calculations were carried out to rationalize the observed stereo-selectivity of the synthesis reaction and other structural and thermodynamic aspects. The cytotoxicity of 2a-f was assessed on cisplatin sensitive and resistant human ovarian carcinoma (A2780 and A2780cisR) cell lines, and human embryonic kidney (HEK-293) cells. Experiments reveal that treatment with the compounds leads to ROS production, with an absence of direct interactions with double stranded DNA (calf thymus) and bovine serum albumin.
\end{abstract}

Keywords: bioorganometallic chemistry, diiron complexes, allylidene ligand, cyanide addition, DFT calculations, cytotoxicity.

\title{
Introduction
}

Transition metal compounds display a range of characteristics providing pharmacological profiles not accessible to organic molecules, ${ }^{1}$ and the anticancer properties of cisplatin led to a paradigm shift in the treatment of various types of tumors. ${ }^{2}$ Nevertheless, although cisplatin and the second generation of platinum drugs are widely applied in the clinic, they exhibit certain limitations, i.e. severe side effects due to limited drug selectivity and progressive resistance acquisition. ${ }^{3}$ Considerable efforts have been 
devoted to the development of new metal drugs overcoming such limitations, thus compounds based on several, alternative transition metals have been proposed as possible anticancer agents. $1^{\mathrm{a}, 4,5}$ Notably, iron has emerged as an attractive metal for drug design, being bio-essential and substantially non-toxic in many forms. ${ }^{6}$ Following the discovery of ferrocene in organometallic chemistry, ${ }^{7}$ diverse ferrocene derivatives have been investigated for their anticancer behavior, ${ }^{8}$ such as compounds functionalized with hydroxytamoxifen-type substituents (ferrocifens) which have promising properties. ${ }^{9}$ In general, the redox chemistry of the iron center appears to be key to the cytotoxicity of these compounds, since oxidation of $\mathrm{Fe}(\mathrm{II})$ to $\mathrm{Fe}(\mathrm{III})$ in the tumor environment is responsible for the production of toxic metabolites. ${ }^{10}$ The ferrocenyl moiety has been tethered to a variety of transition metal based frames to obtain binuclear derivatives with improved cytotoxic properties, ${ }^{11}$ and also certain monoiron complexes with one cyclopentadienyl ligand display potent cytotoxicity against various cancer cell lines. ${ }^{12}$

The anticancer properties of diiron complexes, however, are largely unexplored. Nevertheless, a diiron frame has been shown to supply unique cooperative effects in terms of chemical reactivity, ${ }^{13}$ and offers wide possibilities to design and modify the nature of bridging-coordinated ligands, thus allowing the introduction of the most suitable functional groups to gain full control of fundamental properties for a metal-based drug (e.g., water solubility, lipophilicity, stability, redox potential, etc.). Besides, it should be noticed that only few iron carbonyl compounds have been investigated for their anticancer behavior so far. ${ }^{12 \mathrm{a}, 14}$

The commercially available $\mathrm{Fe}_{2} \mathrm{Cp}_{2}(\mathrm{CO})_{4}$ is the most obvious starting material for the preparation of diiron cyclopentadienyl-carbonyl species, and indeed a wide variety of organometallic architectures can be built on such a dinuclear skeleton through a multitude of strategies involving the progressive substitution of CO ligands. ${ }^{15,16}$

In particular, the sequential assembly of one isocyanide and one alkyne provides easy access to cationic complexes with a bridging vinyliminium ligand (1, Figure 1$),{ }^{17,18}$ displaying a versatile chemistry. ${ }^{19}$ 
Recent studies have shown that these compounds possess a promising anticancer potential, their cytotoxic activity being attributable to a multimodal action, including ROS generation, DNA binding and fragmentation to monoiron species. ${ }^{20}$

Herein, we describe the synthesis and the characterization of a series of new diiron compounds with a functionalized allylidene ligand. Structural aspects have been elucidated by NMR spectroscopy, X-ray diffraction and DFT studies. The cytotoxicity of this new category of potential organometallic anticancer agents has been assessed, and a number of experiments has been conducted to shed light on the mode of action.

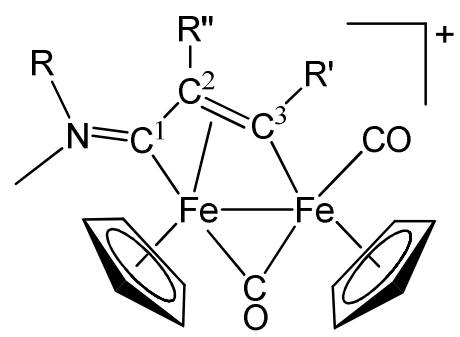

Figure 1. General structure of diiron $\mu$-vinyliminium complexes (counteranion: $\mathrm{CF}_{3} \mathrm{SO}_{3}{ }^{-}$). $\mathrm{R}=$ alkyl or aryl; $\mathrm{R}^{\prime}=$ alkyl, aryl, $\mathrm{CO}_{2} \mathrm{Me}$ or thiophenyl; R" $=\mathrm{H}$, alkyl, $\mathrm{Ph}$ or $\mathrm{CO}_{2} \mathrm{Me}$.

\section{Results and discussion}

\section{Synthesis of compounds, structural characterization and DFT calculations}

The allylidene complexes 2a-e were obtained by the straightforward reactions of the diiron vinyliminium precursors $[\mathbf{1 a}-\mathbf{e}] \mathrm{CF}_{3} \mathrm{SO}_{3}$ with tetrabutylammonium cyanide, in dichloromethane (Scheme 1). The products were isolated in $67-87 \%$ yields after chromatography on alumina. Compound 2f $(63 \%$ yield $)$ could be obtained more conveniently from $[\mathbf{1 f}] \mathrm{CF}_{3} \mathrm{SO}_{3}$ upon reaction with potassium cyanide in methanol, followed by filtration of a dichloromethane solution of the product through celite. 


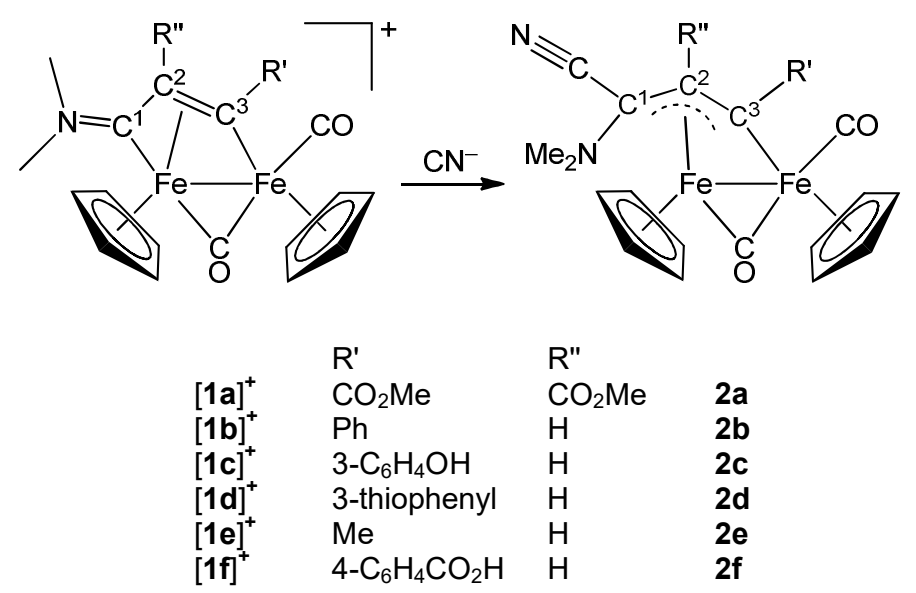

Scheme 1. Synthesis of diiron nitrile-aminoallylidene complexes by cyanide addition to vinyliminium ligands. 2ae: $\mathrm{CN}^{-}$from $\mathrm{NBu}_{4} \mathrm{CN}, \mathrm{CH}_{2} \mathrm{Cl}_{2}$ solution; $\mathbf{2 f}$ : $\mathrm{CN}^{-}$from $\mathrm{KCN}, \mathrm{MeOH}$ solution.

Compounds 2a-f are air stable and soluble in dichloromethane, acetone and dimethylsulfoxide; $\mathbf{2 a}$ and 2f are slightly soluble in water, ${ }^{21}$ whereas $\mathbf{2 b - e}$ are insoluble. All the products were characterized by elemental analysis, IR and NMR spectroscopy, and the structures of $\mathbf{2 b}, \mathbf{2 d}$ and $\mathbf{2 e}$ were ascertained by single crystal X-ray diffraction (Figures 2-4 and Table 1). These structures are composed of a cis$\left[\mathrm{Fe}_{2} \mathrm{Cp}_{2}(\mathrm{CO})(\mu-\mathrm{CO})\right]$ core and a bridging $\left(\mu-\eta^{1}: \eta^{3}\right)$ allylidene ligand, all displaying a mutual syn arrangement of the $C^{2}$-bound hydrogen and the nitrile group. ${ }^{19 c, 22}$ With reference to the iron atoms, two stereoisomers are expected in the cationic precursors, and also $\mathbf{2 a - f}$ are reasonably obtained as racemic mixtures. According to the allylidene nature, both $\mathrm{C}(1)-\mathrm{C}(2)$ and $\mathrm{C}(2)-\mathrm{C}(3)$ bonds $[$ e.g. in $\mathbf{2 b}$ : $1.454(2)$ $\AA$ and 1.413(2) $\AA$, respectively] manifest some $\pi$-character. Moreover, the $\mathrm{Fe}(2)-\mathrm{C}(1), \mathrm{Fe}(2)-\mathrm{C}(2)$ and $\mathrm{Fe}(2)-\mathrm{C}(3)$ distances [in 2b: 2.0633(18) $\AA, 2.0218(17) \AA$ and 2.0423(17) $\AA$, respectively] exhibit minor differences in view of the $\eta^{3}$-coordination of the ligand to $\mathrm{Fe}(2)$. The $\mathrm{Fe}(1)-\mathrm{C}(3)$ distance $[1.9460(18) \AA$ in $\mathbf{2 b}]$ is reminiscent of pure iron-carbon $\sigma$-bonds in similar systems. ${ }^{15 a, 23}$ The $\mathrm{C}(1)-\mathrm{N}(1)$ bond does not show double-bond character, ${ }^{24}$ as also suggested by the fact that it is similar in length to the $\mathrm{N}(1)-\mathrm{C}(4)$ and $\mathrm{N}(1)-\mathrm{C}(5)$ bonds $[$ e.g. in the case of $\mathbf{2 b}$ : $\mathrm{C}(1)-\mathrm{N}(1)=1.449(2) \AA$; $\mathrm{N}(1)-\mathrm{C}(4)=$ $1.466(2) \AA ; \mathrm{N}(1)-\mathrm{C}(5)=1.473(2) \AA]$. Thus, $\mathrm{N}(1)$ displays a sp ${ }^{3}$ hybridization and, accordingly, the sum 
of the angles at $\mathrm{N}(1)$ is far from $360^{\circ}$, as expected for $\mathrm{sp}^{2}$ hybridization. Allylidene ligands bridging two metal centers in a $\left(\mu-\eta^{1}: \eta^{3}\right)$ fashion are not uncommon in organometallic chemistry, and they typically consist of a hydrocarbyl $\mathrm{C}_{3}$ chain. ${ }^{25}$ However, the derivatization of the vinyliminium ligand represents a unique strategy to access allylidene structures stereo-selectively double-substituted.

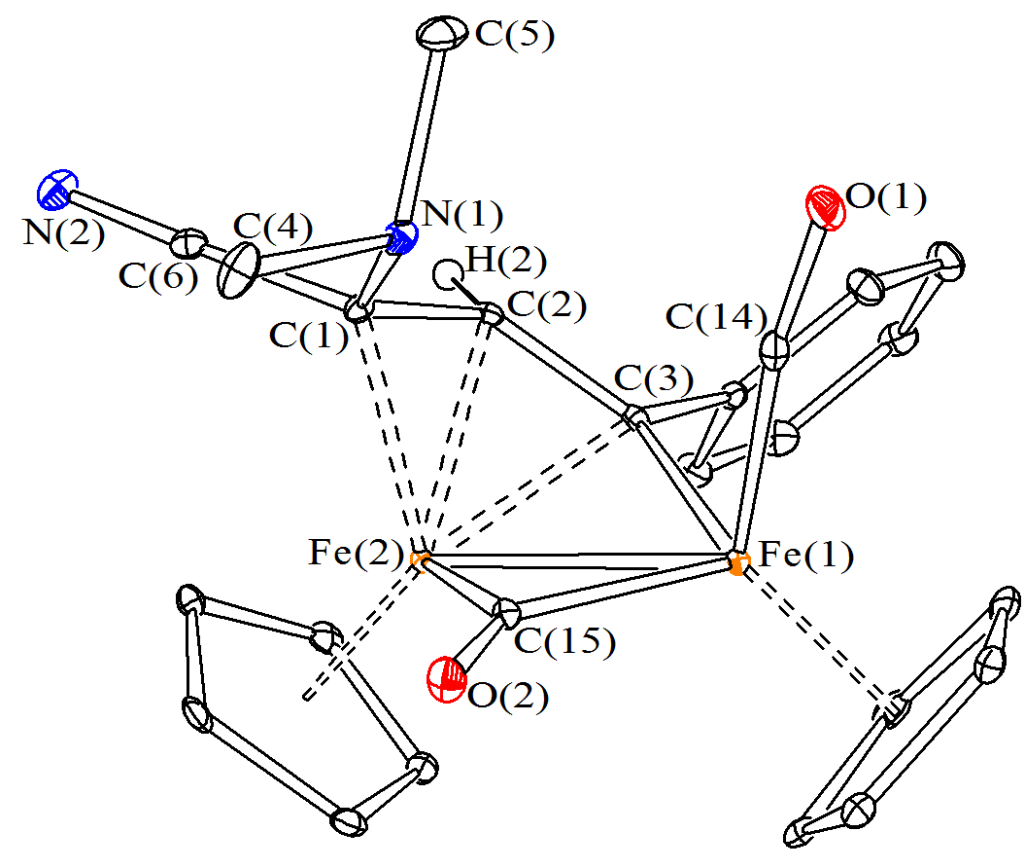

Figure 2. Molecular structure of $\left[\mathrm{Fe}_{2} \mathrm{Cp}_{2}(\mathrm{CO})(\mu-\mathrm{CO})\left\{\mu-\eta^{1}: \eta^{3}-\mathrm{C}^{3}(\mathrm{Ph}) \mathrm{C}^{2} \mathrm{HC}^{1}(\mathrm{CN}) \mathrm{NMe}_{2}\right\}\right]$, 2b. Displacement ellipsoids are at the $30 \%$ probability level. $\mathrm{H}$-atoms, except $\mathrm{H}(2)$, have been omitted for clarity. 


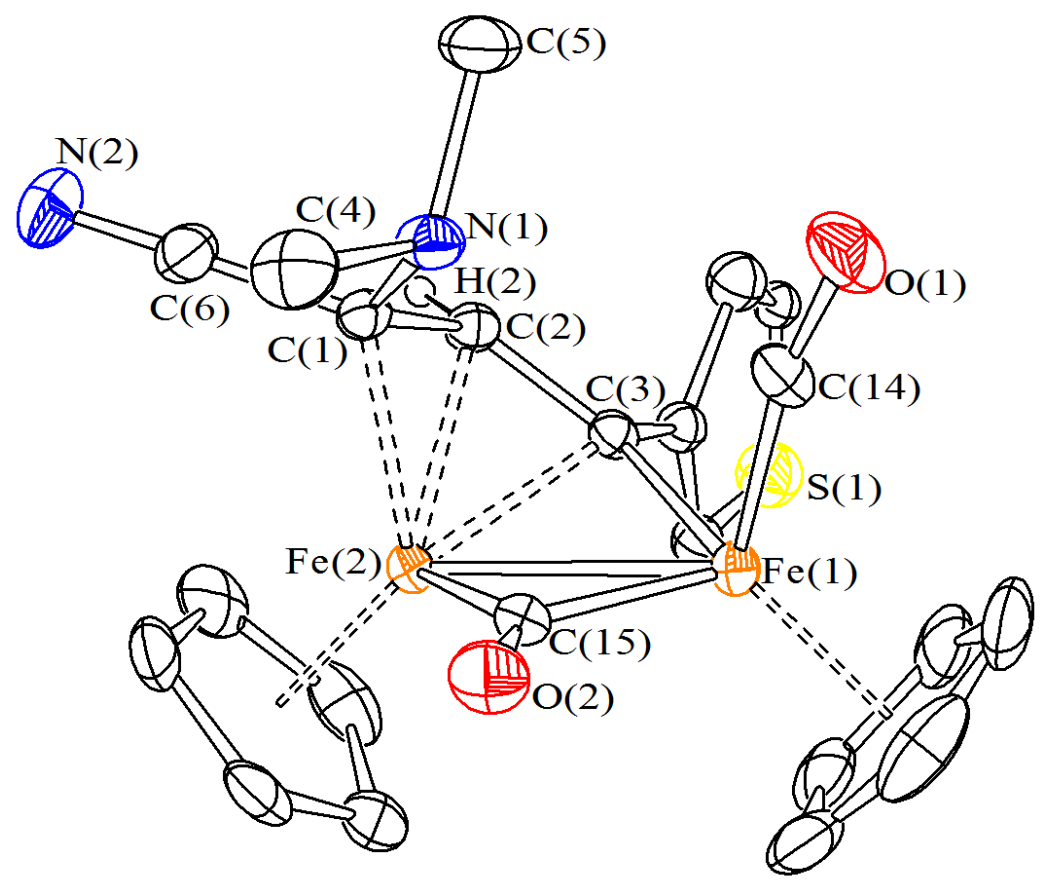

Figure 3. Molecular structure of $\left[\mathrm{Fe}_{2} \mathrm{Cp}_{2}(\mathrm{CO})(\mu-\mathrm{CO})\left\{\mu-\eta^{1}: \eta^{3}-\mathrm{C}^{3}\left(3-\right.\right.\right.$ thiophenyl) $\left.\left.\mathrm{C}^{2} \mathrm{HC} C^{1}(\mathrm{CN}) \mathrm{NMe}_{2}\right\}\right], \quad \mathbf{2 d}$. Displacement ellipsoids are at the $30 \%$ probability level. $\mathrm{H}$-atoms, except $\mathrm{H}(2)$, have been omitted for clarity.

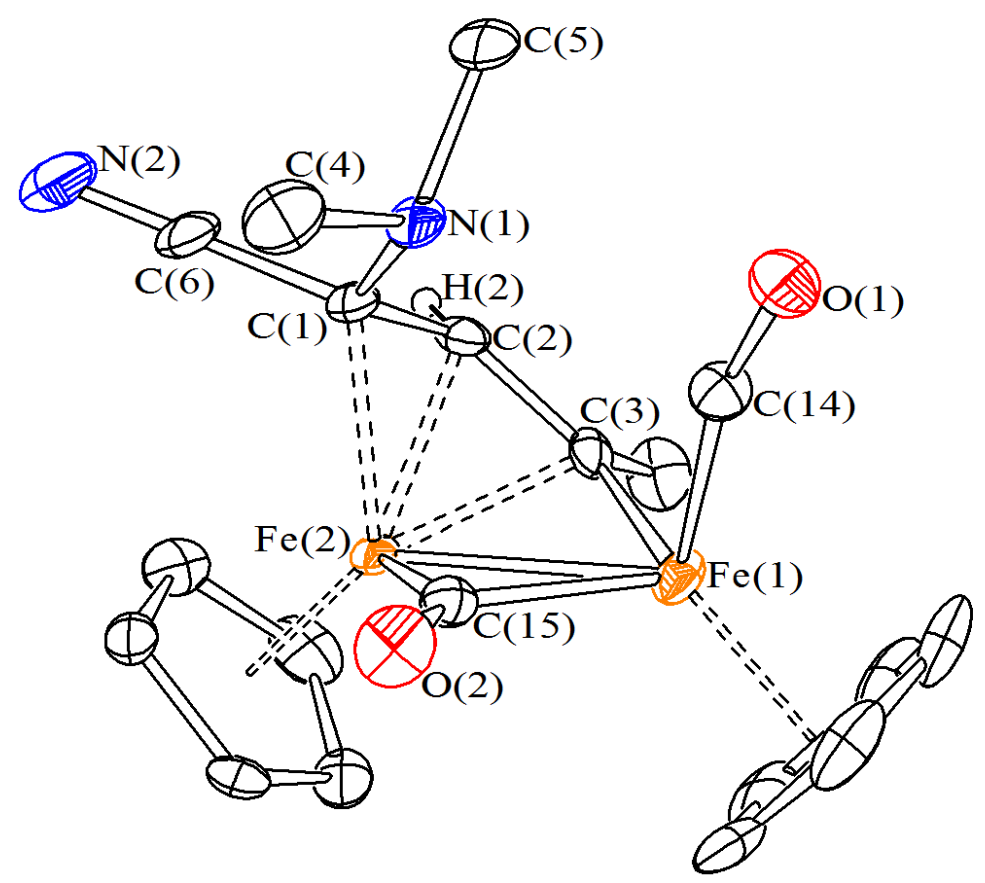

Figure 4. Molecular structure of $\left[\mathrm{Fe}_{2} \mathrm{Cp}_{2}(\mathrm{CO})(\mu-\mathrm{CO})\left\{\mu-\eta^{1}: \eta^{3}-\mathrm{C}^{3}(\mathrm{Me}) \mathrm{C}^{2} \mathrm{HC}^{1}(\mathrm{CN}) \mathrm{NMe}_{2}\right\}\right]$, 2e. Displacement ellipsoids are at the $30 \%$ probability level. $\mathrm{H}$-atoms, except $\mathrm{H}(2)$, have been omitted for clarity. 
Table 1. Selected bond lengths $(\AA)$ and angles $\left({ }^{\circ}\right)$ for $\mathbf{2 b}, \mathbf{2} \mathbf{d}$ and $\mathbf{2 e}$.

\begin{tabular}{|c|c|c|c|}
\hline & $\mathbf{2 b}$ & $\mathbf{2 d}$ & $\mathbf{2 e}$ \\
\hline $\mathrm{Fe}(1)-\mathrm{Fe}(2)$ & $2.5535(4)$ & $2.5535(8)$ & $2.5455(16)$ \\
\hline $\mathrm{Fe}(1)-\mathrm{C}(14)$ & $1.769(2)$ & $1.751(5)$ & $1.765(8)$ \\
\hline $\mathrm{Fe}(1)-\mathrm{C}(15)$ & $1.928(2)$ & $1.936(4)$ & $1.962(8)$ \\
\hline $\mathrm{Fe}(1)-\mathrm{C}(3)$ & $1.946(2)$ & $1.948(4)$ & $1.914(9)$ \\
\hline $\mathrm{Fe}(2)-\mathrm{C}(3)$ & $2.0423(17)$ & $2.041(4)$ & $2.021(7)$ \\
\hline $\mathrm{Fe}(2)-\mathrm{C}(2)$ & $2.0218(17)$ & $2.021(4)$ & $2.000(7)$ \\
\hline $\mathrm{Fe}(2)-\mathrm{C}(1)$ & $2.063(2)$ & $2.065(4)$ & $2.056(7)$ \\
\hline $\mathrm{Fe}(2)-\mathrm{C}(15)$ & $1.933(2)$ & $1.915(5)$ & $1.872(8)$ \\
\hline $\mathrm{C}(14)-\mathrm{O}(1)$ & $1.145(2)$ & $1.134(6)$ & $1.136(10)$ \\
\hline $\mathrm{C}(15)-\mathrm{O}(2)$ & $1.176(2)$ & $1.165(5)$ & $1.166(9)$ \\
\hline $\mathrm{C}(1)-\mathrm{C}(2)$ & $1.454(2)$ & $1.445(6)$ & $1.422(11)$ \\
\hline $\mathrm{C}(2)-\mathrm{C}(3)$ & $1.413(2)$ & $1.412(6)$ & $1.419(11)$ \\
\hline $\mathrm{C}(1)-\mathrm{C}(6)$ & $1.463(2)$ & $1.472(6)$ & $1.459(11)$ \\
\hline $\mathrm{C}(1)-\mathrm{N}(1)$ & $1.449(2)$ & $1.436(6)$ & $1.453(10)$ \\
\hline $\mathrm{C}(4)-\mathrm{N}(1)$ & $1.466(2)$ & $1.461(6)$ & $1.454(11)$ \\
\hline $\mathrm{C}(5)-\mathrm{N}(1)$ & $1.473(2)$ & $1.464(6)$ & $1.454(11)$ \\
\hline $\mathrm{C}(6)-\mathrm{N}(2)$ & $1.149(3)$ & $1.131(6)$ & $1.141(13)$ \\
\hline $\mathrm{Fe}(1)-\mathrm{C}(14)-\mathrm{O}(1)$ & $169.9(2)$ & $168.5(5)$ & $164.8(8)$ \\
\hline $\mathrm{Fe}(1)-\mathrm{C}(15)-\mathrm{Fe}(2)$ & $82.82(7)$ & $83.06(18)$ & $83.2(3)$ \\
\hline $\mathrm{Fe}(1)-\mathrm{C}(3)-\mathrm{Fe}(2)$ & $79.58(6)$ & $79.58(16)$ & $80.6(3)$ \\
\hline $\mathrm{Fe}(1)-\mathrm{C}(3)-\mathrm{C}(2)$ & $126.31(13)$ & $125.1(3)$ & $125.8(6)$ \\
\hline $\mathrm{C}(3)-\mathrm{C}(2)-\mathrm{C}(1)$ & $123.83(16)$ & $124.7(4)$ & $123.2(7)$ \\
\hline $\mathrm{Sum}$ at N(1) & $332.6(3)$ & $335.0(7)$ & $336.8(12)$ \\
\hline $\mathrm{C}(2)-\mathrm{C}(1)-\mathrm{C}(6)$ & $111.99(15)$ & $111.8(4)$ & $116.3(8)$ \\
\hline $\mathrm{C}(1)-\mathrm{C}(6)-\mathrm{N}(2)$ & $177.1(2)$ & $178.6(6)$ & $175.8(12)$ \\
\hline
\end{tabular}

The geometry of $\mathbf{2 b}$ was optimized by DFT calculations and the computed structure is shown in the Supporting Information (Figure S1), together with a comparison of calculated and experimental (X-ray) parameters (Table S1). The agreement is generally good, with a notable exception being the $\mathrm{N}(1){ }^{\cdots} \mathrm{C}(14)$ distance which is considerably shorter in the DFT structure [2.425 $\AA$ vs. 2.793(2) $\AA$ ]. 
Presumably the weak interaction between the N(1) lone pair and the electrophilic carbon of the terminal carbon monoxide is enhanced in the isolated molecule, whereas in the crystal packing intermolecular interactions (such as $\mathrm{CH} / \pi, \mathrm{CH} / \mathrm{O}$ and $\mathrm{CH} / \mathrm{N}$ ) weakens this bond. In solution, the $\mathrm{N}(1) \cdots \mathrm{C}(14)$ interaction is expected to become important, at least in nonpolar solvents that are not able to compete with $\mathrm{CO}$ for the lone pair of the amine group. The Mayer bond orders (b.o.) calculated for 2b are $0.9,1.03,1.1$ and 0.8 for $\mathrm{C}(1)-\mathrm{N}(1), \mathrm{C}(1)-\mathrm{C}(2), \mathrm{C}(2)-\mathrm{C}(3)$ and $\mathrm{C}(1)-\mathrm{C}(6)$, respectively, and 0.65 , 0.60 and 0.84 for $\mathrm{Fe}(1)-\mathrm{C}(1), \mathrm{Fe}(1)-\mathrm{C}(3)$ and $\mathrm{Fe}(2)-\mathrm{C}(3)$, respectively. These data confirm the description of the bridging $\mathrm{C}_{3}$ ligand as an allylidene.

The DFT-optimized geometry of $\mathbf{2} \mathbf{b}^{\mathbf{}}$, wherein the nitrile group and the $\mathrm{C}^{2}$-bound hydrogen adopt the mutual anti-configuration (Figure S2), is $7.3 \mathrm{kcal} \mathrm{mol}^{-1}$ less stable than $\mathbf{2 b}$. Two factors may explain the minor stability of $\mathbf{2} \mathbf{b}^{\prime}:$ i) the above described amine-CO interaction is no longer viable $[\mathrm{N}(1) \cdots \mathrm{C}(14)=4.722 \AA]$; ii) the $[\mathrm{C} \equiv \mathrm{N}]$ moiety faces the terminal carbonyl and an electronic repulsion between the respective $\pi$ clouds is expected.

The calculated structures of $\mathbf{3 a}$ and $\mathbf{3 b}$ (Figure S3) were obtained by replacement of the nitrile substituent with a hydrogen, starting from $\mathbf{2 b}^{\mathbf{1}}$ and $\mathbf{2} \mathbf{b}$, respectively. When the $\mathrm{C}^{1}-\mathrm{H}$ and $\mathrm{C}^{2}-\mathrm{H}$ hydrogens are syn $(\mathbf{3 b})$, the amino group and the terminal $\mathrm{CO}$ are sufficiently close to interact $[\mathrm{N}(1) \cdots \mathrm{C}(14)=2.608 \AA]$. The opposite configuration (3a) does not allow such interaction $\left[\mathrm{N}(1)^{\cdots} \mathrm{C}(14)=4.264 \AA\right]$, nevertheless the reduced steric repulsion between the $\mathrm{C}^{1}$-substituents and the terminal CO leads to the increased stability of $\mathbf{3 a}$ with respect to $\mathbf{3 b}$ by $11.1 \mathrm{kcal} / \mathrm{mol}$. In agreement with this computational outcome, compounds analogous to 3a were previously obtained by stereoselective hydride addition to vinyliminium complexes; ${ }^{26}$ alkylation of these compounds is feasible as a consequence of the availability of the amine lone pair, not involved in any interaction with $\mathrm{CO} .^{27}$

The IR spectra of $2 \mathbf{a}-\mathbf{f}\left(\mathrm{CH}_{2} \mathrm{Cl}_{2}\right.$ solution) are similar, exhibiting two strong bands due to the terminal and bridging carbonyls (e.g. in the case of $\mathbf{2 b}$, at 1970 and $1787 \mathrm{~cm}^{-1}$, respectively), and a less intense 
absorption related to the nitrile group (around $\left.2190 \mathrm{~cm}^{-1}\right)$. The ${ }^{1} \mathrm{H}$ and ${ }^{13} \mathrm{C} \mathrm{NMR} \mathrm{spectra} \mathrm{of} \mathbf{2 a}-\mathbf{f}\left(\mathrm{CDCl}_{3}\right.$ or acetone- $\mathrm{d}_{6}$ solution) consist in single sets of resonances, indicating a stereo-selective addition of the cyanide ion to the parent vinyliminium compounds. In accordance with the X-ray and DFT structures, the nitrile group is expected to occupy a syn position with respect to the $C^{2}$-substituent. The $C^{1}, C^{2}$ and $\mathrm{C}^{3}$ carbons exhibit signals in the ranges $57.1-65.8 \mathrm{ppm}, 81.3-84.6 \mathrm{ppm}$ and $184.6-201.6 \mathrm{ppm}$, respectively. The chemical shift of $\mathrm{C}^{3}$, whose variability is in alignment with the different substituents, is indicative of a bridging alkylidene carbon. ${ }^{13 b, 28}$ The N-bound methyl groups give rise to two singlets in the NMR spectra [e.g. for $\mathbf{2 b}$ : $\left.\delta\left({ }^{1} \mathrm{H}\right)=2.39,1.87 \mathrm{ppm} ; \delta\left({ }^{13} \mathrm{C}\right)=49.6,42.0 \mathrm{ppm}\right]$. On account of the single bond character of $\mathrm{C}^{1}-\mathrm{N}$, this spectroscopic feature reflects the inhibition of both the rotation of the $\left[\mathrm{NMe}_{2}\right]$ group around the $\mathrm{C}^{1}-\mathrm{N}$ axis and the $\mathrm{N}$-lone pair inversion, presumably due to a $\mathrm{N}-\mathrm{CO}$ interaction.

In order to better clarify this point, we prepared the vinyliminium $[\mathbf{1 g}] \mathrm{CF}_{3} \mathrm{SO}_{3}$, containing one methyl and one naphthyl bound to nitrogen, then this compound was reacted with $\mathrm{NBu}_{4} \mathrm{CN}$ in $\mathrm{CH}_{2} \mathrm{Cl}_{2}(\mathrm{Scheme}$ 2). Cyanide addition still takes place selectively at the $C^{1}$ carbon to give the allylidene product 4 .

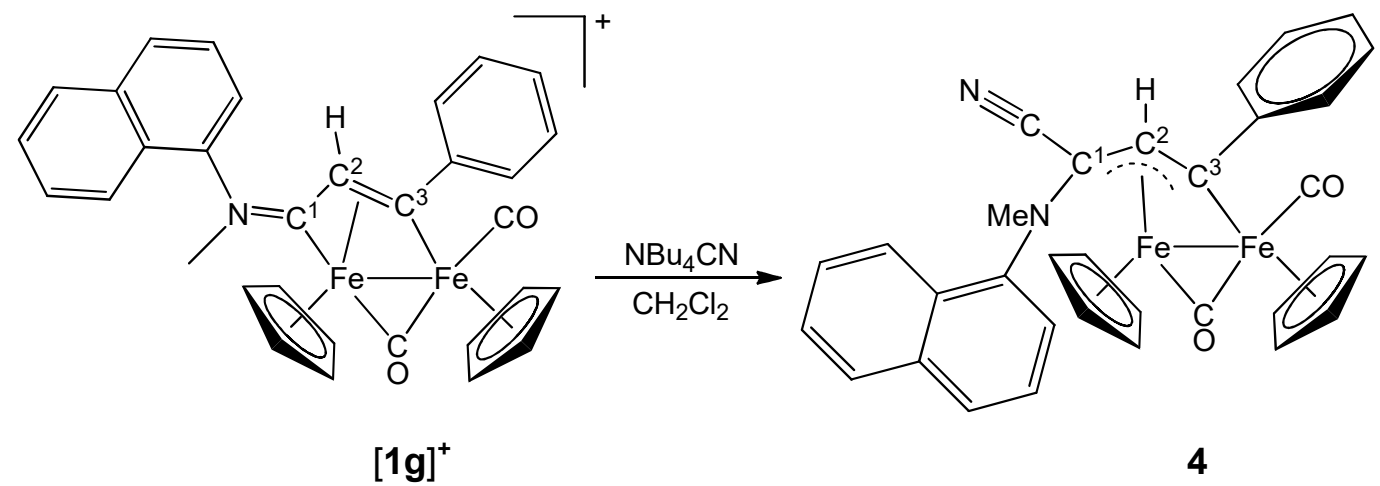

Scheme 2. Cyanide addition to a diiron vinyliminium complex with a naphthyl N-substituent.

Consistent with the spectroscopic features collected for $\mathbf{2 a - f}$, two hypothetical stereoisomers of $\mathbf{4}$ could exist. Indeed, the NMR spectrum of 4 (in acetone- $\mathrm{d}_{6}$ ) contain two sets of resonances, in a relative ratio of 1.4. The most significant differences between the two forms $(\mathbf{4 A}$ and $\mathbf{4 B})$ concern the ${ }^{13} \mathrm{C}$ resonances 
of the bridging CO (264.3 and $258.8 \mathrm{ppm}$ in the two species, respectively), the ipso-carbon belonging to the naphthyl moiety (149.2 and $145.5 \mathrm{ppm}$ ) and the methyl substituent (47.6 and $42.0 \mathrm{ppm}$ ). These data confirm that $\mathbf{4 A}$ and $\mathbf{4 B}$ differ from each other in the orientation of the nitrogen substituents. Views of the DFT-optimized structures of $\mathbf{4 A}$ and $\mathbf{4 B}$ are shown in Figure 5. Isomer $\mathbf{4 A}$, with the naphthyl group oriented on the same side of the bridging carbonyl, is slightly more stable than $\mathbf{4 B}$ by $2.6 \mathrm{kcal} \mathrm{mol}^{-1}$.

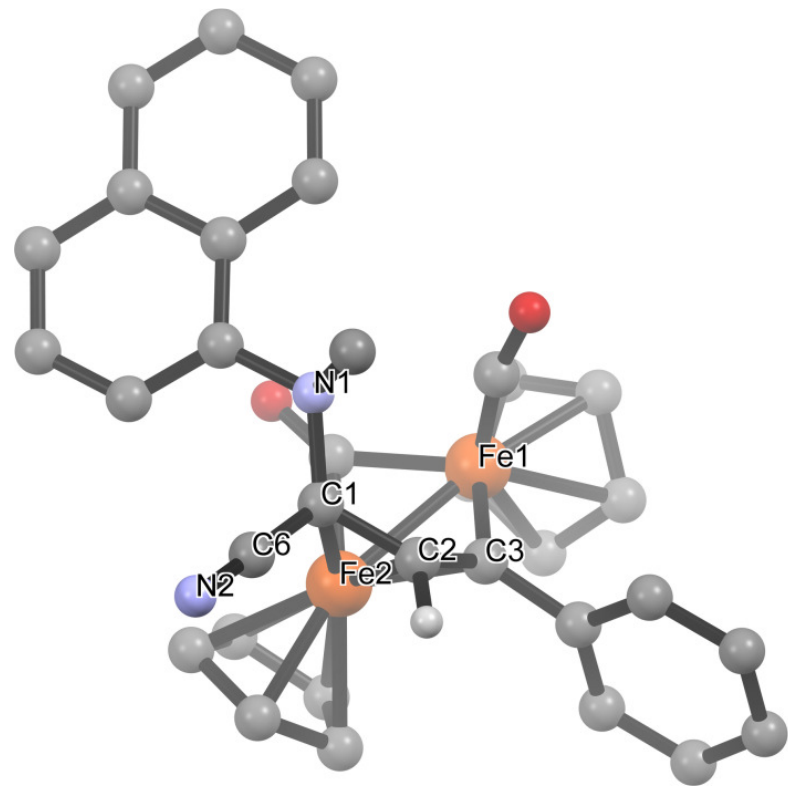

4A

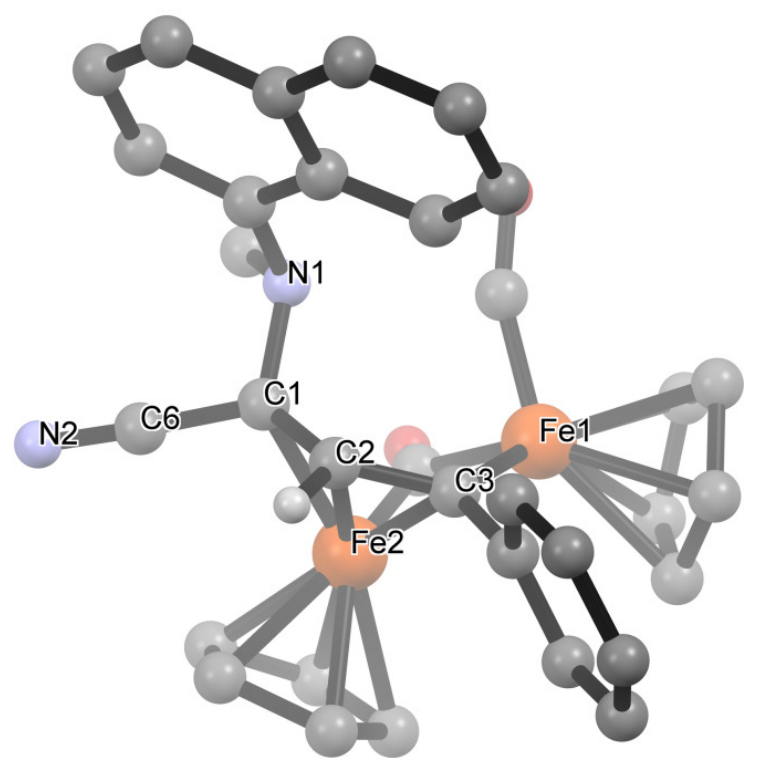

4B

Figure 5. DFT calculated structures of the stereo-isomers of $\left[\mathrm{Fe}_{2} \mathrm{Cp}_{2}(\mathrm{CO})(\mu-\mathrm{CO})\left\{\mu-\eta^{1}: \eta^{3}-\mathrm{C}^{3}(\mathrm{Ph}) \mathrm{C}^{2} \mathrm{HC}^{1} \mathrm{HNMe}_{2}\right\}\right]$, 4. All hydrogen atoms (except $\mathrm{C}^{2}-\mathrm{H}$ ) have been omitted for clarity.

\section{Electrochemistry}

The redox behavior of $\mathbf{2 a - f}$ was investigated by cyclic voltammetry at a platinum electrode in $\mathrm{DMSO} /\left[\mathrm{N}^{\mathrm{n}} \mathrm{Bu}_{4}\right] \mathrm{PF}_{6} \quad 0.1 \mathrm{M}$. In all cases, the $\mathrm{CV}$ profiles consist of one electrochemically quasireversible reduction (peak-to-peak separation $\Delta E_{\mathrm{p}}=90 \div 113 \mathrm{mV}$ and current function $i_{\mathrm{p}} / v^{1 / 2}$ not 
constant), and one oxidation. The latter is complicated by subsequent fast chemical reactions, as shown by the appearance of new reduction processes during the back scan toward negative potentials, in a double cycle CV experiment (Figure 6, red line) performed on 2e. By cycling the potential between -0.65 and $+0.35 \mathrm{~V}(\mathbf{2 e})$, we ascertained that peak B is the cathodic counterpart of the reduction A, indicating that the $\mathrm{A} / \mathrm{B}$ peak system is related to a stable species produced after the oxidation occurring at $+0.07 \mathrm{~V}$. Moreover, the oxidation peak is much more intense than that related to the reversible reduction at $-1.89 \mathrm{~V}$. Hydrodynamic voltammetry at a rotating disk electrode was used to verify that, during the oxidation process, the limiting current is approximately fourfold compared to the reduction current. The formal reduction potentials and the anodic peak potentials for the observed electron transfers of 2a-f are compiled in Table 2; a graphic comparison (Figure S4) highlights that the two carboxylato substituents in $\mathbf{2 a}$ significantly move both the redox processes toward positive potentials, and remarkably this compound exhibits the higher $\mathrm{IC}_{50}$ value (vide infra). It should be noted that the strongest oxidant in the biological environment is $\mathrm{O}_{2}$ (standard apparent reduction potential $+0.815 \mathrm{~V}$ vs. NHE, namely +0.615 vs $\mathrm{Ag} / \mathrm{AgCl} \mathrm{KCl} \mathrm{sat);} \mathrm{assuming} \mathrm{that} \mathrm{the} \mathrm{trend} \mathrm{of} \mathrm{potentials} \mathrm{assessed} \mathrm{for} \mathbf{2 a - f}$ is approximately maintained in a physiological medium, the oxidation potential of $\mathbf{2 a}$ would be the only one outside the biologically relevant range. 


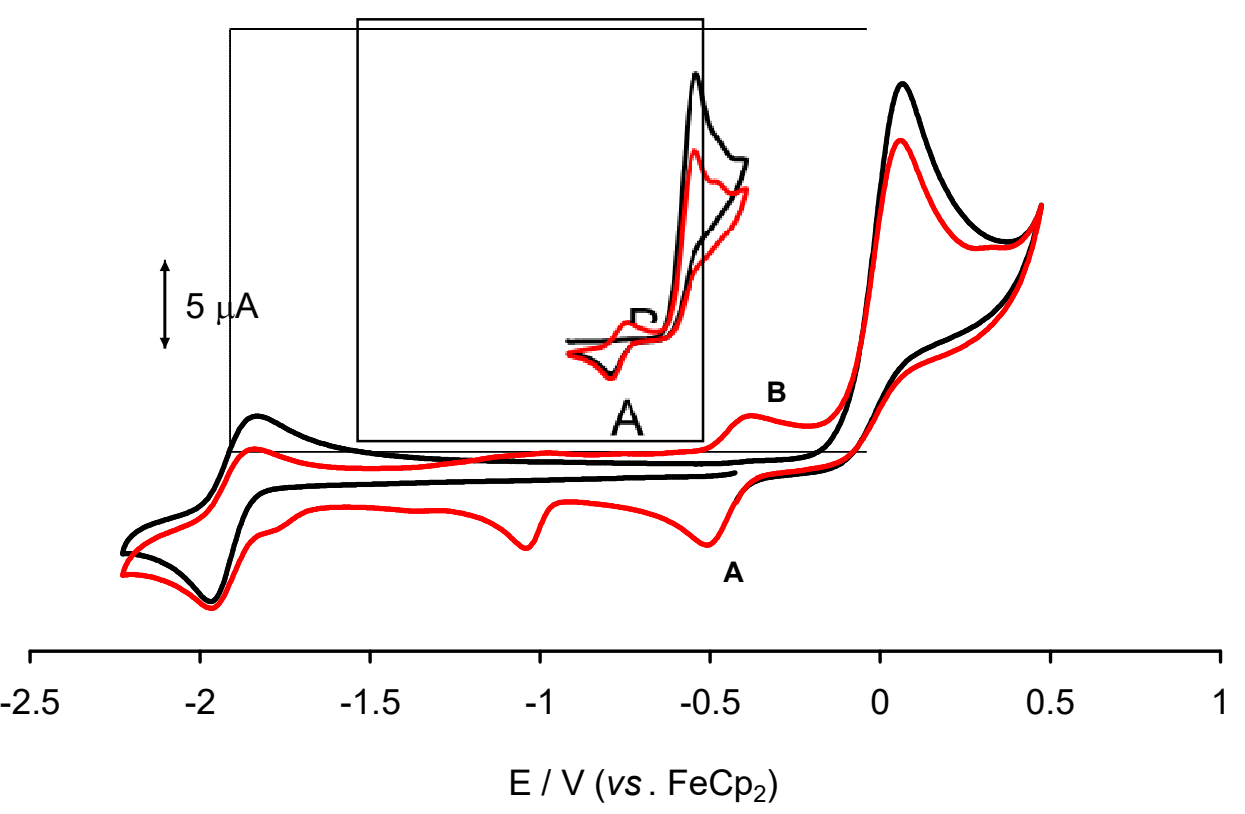

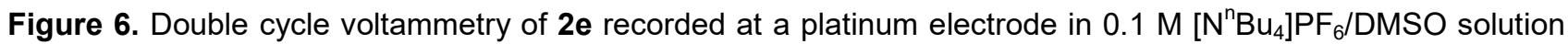
(black line, first cycle; red line, second cycle). Inset: CV of the same solution between -0.65 and $+0.35 \mathrm{~V}$.

Table 2. Formal electrode potential ( $\mathrm{V} v s$. $\mathrm{FeCp}_{2}$, and in brackets $v s \mathrm{Ag} / \mathrm{AgCl}-\mathrm{KCl}$ sat.) and peak-to-peak separations $(\mathrm{mV})$ for redox processes in $\mathrm{DMSO} /\left[\mathrm{N}^{\mathrm{n}} \mathrm{Bu}_{4}\right] \mathrm{PF}_{6} 0.1 \mathrm{M}$. ${ }^{\mathrm{a}}$ Measured at $0.1 \mathrm{~V} \mathrm{~s}^{-1}$. ${ }^{\mathrm{b}}$ Peak potential value for irreversible processes.

\begin{tabular}{|c|c|c|c|}
\hline \multirow[b]{2}{*}{ Compound } & \multicolumn{2}{|c|}{ Reduction } & \multirow{2}{*}{$\frac{\text { Oxidation }}{\mathrm{E}_{\mathrm{pa}}^{\mathrm{b}}}$} \\
\hline & $E_{1}^{\circ \prime}$ & $\Delta \mathrm{E}_{1}^{\mathrm{a}}$ & \\
\hline $2 a$ & $\begin{array}{c}-1.66 \\
(-1.10)\end{array}$ & 86 & $\begin{array}{c}+0.26 \\
(+0.82)\end{array}$ \\
\hline $2 b$ & $\begin{array}{c}-1.89 \\
(-1.33)\end{array}$ & 120 & $\begin{array}{c}+0.07 \\
(+0.63)\end{array}$ \\
\hline 2c & $\begin{array}{c}-1.86 \\
(-1.30)\end{array}$ & 90 & $\begin{array}{c}+0.07 \\
(+0.63)\end{array}$ \\
\hline $2 d$ & $\begin{array}{c}-1.89 \\
(-1.33)\end{array}$ & 110 & $\begin{array}{c}+0.03 \\
(+0.59)\end{array}$ \\
\hline $2 e$ & $\begin{array}{c}-1.90 \\
(-1.34)\end{array}$ & 113 & $\begin{array}{c}+0.07 \\
(+0.63)\end{array}$ \\
\hline $2 f$ & $\begin{array}{c}-1.79 \\
(-1.23)\end{array}$ & 110 & $\begin{array}{c}+0.11 \\
(+0.67)\end{array}$ \\
\hline
\end{tabular}

The redox changes of $2 \mathrm{e}$ in $\mathrm{DMSO} /\left[\mathrm{N}^{\mathrm{n}} \mathrm{Bu}_{4}\right] \mathrm{PF}_{6}$ were subjected to a spectroelectrochemical investigation in an OTTLE cell. When the working electrode potential was progressively decreased from -0.5 to $-2.1 \mathrm{~V}$ (scan rate $\left.=2 \mathrm{mV} \mathrm{s}^{-1}\right)$, the IR absorptions of $2 \mathbf{e}\left(2184,1954\right.$ and $\left.1779 \mathrm{~cm}^{-1}\right)$ were 
progressively replaced by new bands at lower wavenumbers $\left(2166,2150,1881,1740\right.$ and $1700 \mathrm{~cm}^{-1}$, Figure S5A). These bands have been attributed to the reversible formation of two forms of $[\mathbf{2 e}]^{-}$, as suggested by the doubling of the $\mathrm{CN}$ stretching bands and the presence of one additional carbonyl absorption. One of these forms exhibits one terminal $\left(1881 \mathrm{~cm}^{-1}\right)$ and one bridging carbonyl ligand $\left(1700 \mathrm{~cm}^{-1}\right)$, vide infra. Before the complete disappearance of the IR absorptions related to $2 \mathrm{e}$, the occurrence of a weak band at $1914 \mathrm{~cm}^{-1}$ evidenced the scarce stability of the reduced species (on the spectroelectrochemical experiment time scale). Accordingly, the backward potential scan until the initial value of $-0.5 \mathrm{~V}$ did not allow the complete recovery of $2 \mathrm{e}$ (Figure S5B).

In parallel, the geometry of $[\mathbf{2 b}]^{-}$(doublet spin state) was optimized by DFT calculations (Figure S7). The most significant change on going from $\mathbf{2} \mathbf{b}$ to $[\mathbf{2 b}]^{-}$(Table S2) is the elongation of the Fe-Fe (from $2.528 \AA$ to $2.676 \AA$ ) and $\mathrm{N}(1)^{\cdots} \mathrm{C}(14)$ distances (from $2.425 \AA$ to $2.790 \AA$ ). Presumably the increased electron density on the iron atoms in $[\mathbf{2 b}]^{-}$determines a reciprocal repulsion. Consequently, the terminal $\mathrm{CO}$ ligand receives increased back-donation from $\mathrm{Fe}(2)$, thus weakening the interaction with the amine group. The computed IR frequency of the terminal CO moves from 1863 (2b) to 1795 ([2b] $\left.]^{-}\right)$, whereas that of the bridging CO moves from $1748(\mathbf{2 b})$ to $1622 \mathrm{~cm}^{-1}\left([\mathbf{2 b}]^{-}\right)$. Accounting for the systematic discrepancy between experimental and computed spectra $\left(\sim 80 \mathrm{~cm}^{-1}\right)$, the two absorptions for $[\mathbf{2 b}]^{-}$are in good agreement with the experimental bands at 1881 and $1700 \mathrm{~cm}^{-1}$ detected during the reduction of $2 \mathbf{e}$ (see above).

The irreversible oxidation of $\mathbf{2 e}$ was also investigated by spectroelectrochemistry. As the working electrode potential was progressively increased from -0.8 to $0.0 \mathrm{~V}$ (scan rate $=2 \mathrm{mV} \mathrm{s}^{-1}$ ), the most significant change in the IR spectrum corresponds to the disappearance of the bridging $\mathrm{CO}$ band at $1779 \mathrm{~cm}^{-1}$, being replaced by a new terminal $\mathrm{CO}$ band at $2009 \mathrm{~cm}^{-1}$. Concurrently, the $\mathrm{C} \equiv \mathrm{N}$ stretching vibration at $2184 \mathrm{~cm}^{-1}$ was progressively substituted by a higher frequency absorption at $2216 \mathrm{~cm}^{-1}$ (Figure S6A). The irreversible nature of the oxidation was ascertained by the backward scan of the 
potential up to $-0.8 \mathrm{~V}$ that did not lead to changes in the IR spectra. These observations suggests that the oxidation is followed by a fast decomposition of the dinuclear compound $[\mathbf{2 e}]^{\mathrm{n}+}$, presumably generating a monoiron dicarbonyl complex $\left(v_{\mathrm{CO}}=2009\right.$ and $\left.1953 \mathrm{~cm}^{-1}\right)$, which cannot be reduced during the reverse potential scan, and one IR silent compound responsible for the A/B peak system of the voltammetric profile showed in Figure 6 . When the working electrode potential was further increased from 0.0 to $+0.4 \mathrm{~V}$, oxidation of the new dicarbonyl species occurred, with the $\mathrm{CO}$ stretching frequencies moving to 2030 and $1982 \mathrm{~cm}^{-1}$ (Figure S6B). Despite of the presence of isosbestic points (Figure S6B), even this oxidation is irreversible and no wavenumber shift was observed during the backward reduction scan until $-0.8 \mathrm{~V}$. In accordance with the spectroelectrochemical data, the treatment of $2 \mathbf{e}$ with a slight molar excess of silver triflate in DMSO leads, after a few hours, to the partial consumption of $2 \mathbf{e}$ and the appearance of a new IR band at $2009 \mathrm{~cm}^{-1}$.

DFT optimization of $[\mathbf{2 b}]^{+}$(doublet spin state, Figure S7 and Table S2) led to shortened Fe-Fe (2.438 $\AA$ ) and $\mathrm{N}(1)^{\cdots} \mathrm{C}(14)$ distances $(1.962 \AA)$. The subsequent reinforcement of the interaction between the terminal $\mathrm{CO}$ and the $\left[\mathrm{NMe}_{2}\right]$ group has a profound impact on the vibrational pattern of the complex. Indeed, the vibrations related to the carbonyl moieties are coupled in $[\mathbf{2} \mathbf{b}]^{+}$, giving rise to two absorptions at $1731 \mathrm{~cm}^{-1}$ (asymmetric vibration) and $1755 \mathrm{~cm}^{-1}$ (symmetric vibration). Since no bands appear in the experimental spectrum of oxidized $2 \mathrm{e}$ in the region $1800-1850 \mathrm{~cm}^{-1}$, the DFT calculations corroborate the hypothesis of fast chemical degradation of the oxidized form of $2 \mathbf{e}$.

\section{Cytotoxicity and ROS assessment}

The stability of 2a-f in aqueous media was initially evaluated under conditions resembling those of the cytotoxicity assays $\left(T=37{ }^{\circ} \mathrm{C}\right.$, time $=72$ hours $)$, with $\mathbf{2 a - f}$ being reasonably stable in $\mathrm{D}_{2} \mathrm{O} / \mathrm{dmso}-\mathrm{d}_{6}$ solution (ca. 2:1 v/v). Indeed the ${ }^{1} \mathrm{H}$ NMR spectra of the final solutions did contain the resonances attributed to $\mathbf{2 a - f}$ and only minor signals due to newly generated species $(<10 \%)$. Moreover, $\mathbf{2 a - f}$ were 
recovered as the only carbonyl-containing compounds after interaction with the cell culture medium (see Experimental for details). A gas-chromatographic analysis carried out on a sample of 2e, left in contact with the cell culture medium for 72 hours, clearly revealed the release of a significant amount of carbon monoxide. The octanol-water partition coefficients $\left(\log P_{\text {ow }}\right)$ were assessed spectrophotometrically using the shake-flask method (Table 3).

The cytotoxicity of 2a-f was assessed against cisplatin sensitive and cisplatin resistant human ovarian carcinoma (A2780 and A2780cisR) cell lines and the non-tumoral human embryonic kidney (HEK293) cell line. The $\mathrm{IC}_{50}$ values are compiled in Table 3 , with cisplatin and $\left[\mathrm{RuCl}_{2}\left(\eta^{6}-\mathrm{p}-\mathrm{cymene}\right)(\kappa P-\right.$ pta)] (RAPTA-C $)^{29}$ evaluated as positive and negative controls, respectively. The cytotoxicity is strongly dependent on the allylidene substituents, ranging from inactive $\left(\mathrm{IC}_{50}>200 \mu \mathrm{M}\right.$, compound 2a) to the low micromolar range. In particular, $\mathbf{2 b}$ exhibits the highest activity and an appreciable selectivity (ca. three-fold) towards the cancer cell lines compared to HEK-293. Moreover, 2b-f display comparable or even lower $\mathrm{IC}_{50}$ values against the cisplatin-resistant cells respect to the cisplatin sensitive ones. This feature, indicating that $\mathbf{2 b - f}$ operate via a markedly different mode of action than cisplatin, has been observed in some related studies on non-platinum based compounds. ${ }^{30}$

Table 3. $\mathrm{Log} P_{\mathrm{ow}}$ values and $\mathrm{IC}_{50}$ values $(\mu \mathrm{M})$ determined for compounds 2a-f, [1a-f] $\mathrm{CF}_{3} \mathrm{SO}_{3},{ }^{17}$ cisplatin and RAPTA-C on human ovarian carcinoma (A2780), human ovarian carcinoma cisplatin resistant (A2780CisR) and human embryonic kidney (HEK-293) cell lines after 72 hours exposure. $I_{50}$ values are given as the mean \pm SD.

\begin{tabular}{ccccc}
\hline Compnd. & Log $\boldsymbol{P}_{\text {ow }}$ & A2780 & A2780cisR & HEK-293 \\
\hline 2a & 0.77 & $>200$ & $>200$ & $>200$ \\
2b & 0.86 & $16 \pm 1$ & $17 \pm 1$ & $50 \pm 6$ \\
2c & 1.00 & $22 \pm 2$ & $14 \pm 2$ & $12 \pm 2$ \\
2d & 1.06 & $22 \pm 3$ & $20 \pm 1$ & $53 \pm 5$ \\
2e & 0.75 & $48 \pm 4$ & $30 \pm 2$ & $55 \pm 5$ \\
2f & 0.16 & $54 \pm 6$ & $44 \pm 7$ & $24 \pm 4$ \\
RAPTA-C & & $>200$ & $>200$ & $>200$ \\
cisplatin & & $2.3 \pm 0.6$ & $31 \pm 3$ & $8.4 \pm 0.9$
\end{tabular}


Intracellular ROS production, monitored by fluorescence measurements using the DCFH-DA assay, was assessed in the A2780 cells treated with $\mathbf{2 d}$ or $\mathbf{2 f}$. The A2780 cells were continuously exposed to 2d, 2f, cisplatin (reference compound) or $\mathrm{H}_{2} \mathrm{O}_{2}$ (positive control), with $\mathbf{2 d}$ and $\mathbf{2 f}$ both inducing an appreciable increase in ROS production (Figure 7). The ROS level detected in the A2780 cells treated with the more cytotoxic compound $\mathbf{2 d}$ was higher than that of $\mathbf{2 f}$. Indeed, $\mathbf{2 f}$ induced noticeable ROS production after ca. 20 hours treatment, whereas ROS formation triggered by $\mathbf{2 d}$ was considerably higher than the positive control $\left(\mathrm{H}_{2} \mathrm{O}_{2}\right)$ even after 3 hours, and progressively increased up to 24 hours.
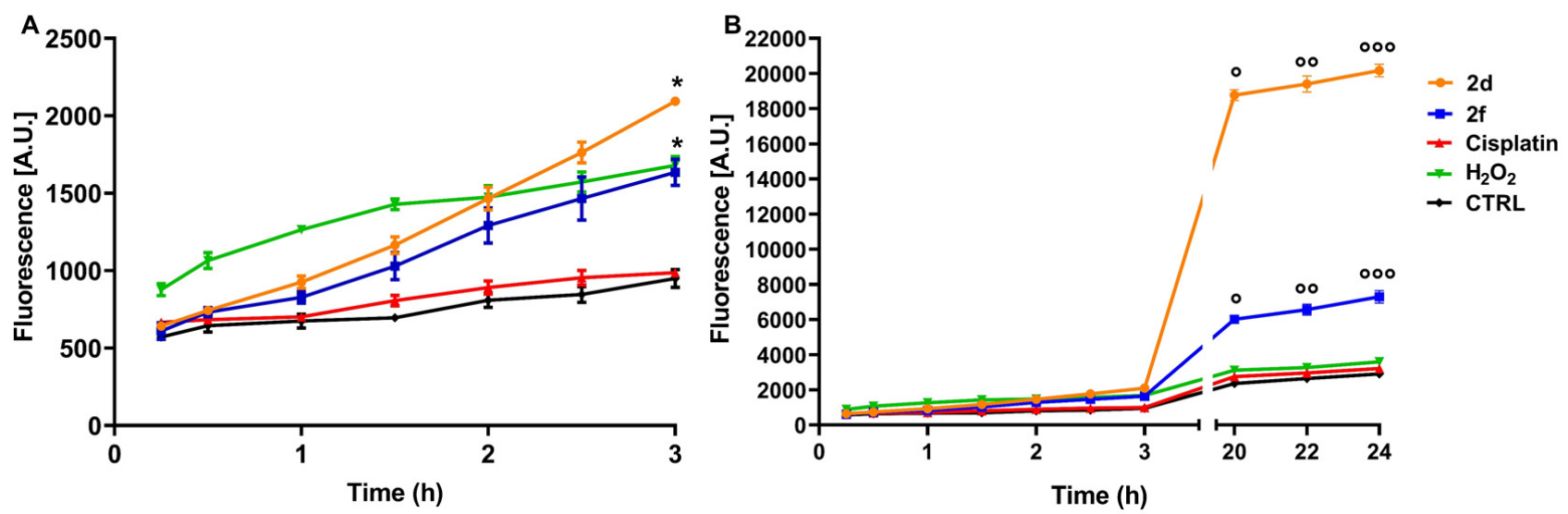

Figure 7. Fluorescence kinetic measurements of intracellular reactive oxygen species (ROS). A2780 cells incubated for (A) 3 hours and (B) 24 hours with $50 \mu \mathrm{M}$ of iron compounds at $37{ }^{\circ} \mathrm{C}$ and $5 \% \mathrm{CO}_{2}$. N.B.: values marked with the same number of ${ }^{*}$ and ${ }^{\circ}$ are significantly different when compared to each other $(p<0.05)$.

\section{Interaction of $\mathbf{2 b}$ with biomolecules}

Due to the efficacy of $\mathbf{2} \mathbf{b}$, its reactivity with DNA and a model protein was studied. Direct spectrophotometric titrations with natural double stranded DNA showed no change in the $2 \mathbf{b}$ absorbance profile upon addition of increasing amounts of DNA (Figure S8A). In a different experiment, DNA was saturated with ethidium bromide (EtBr) (EtBr intercalation into DNA produces fluorescence emission), ${ }^{31}$ then $\mathbf{2 b}$ was added to the EtBr/DNA mixture. No significant change in the 
fluorescence signal was observed with respect to the control (Figure S8B), indicating that $\mathbf{2 b}$ does not interact with DNA. Possible interactions of $\mathbf{2 b}$ with bovine serum albumin (BSA) were also investigated. Negligible variations in the intrinsic fluorescence emission of BSA were detected upon $\mathbf{2 b}$ addition (see comparison with a blank test, Figure S8C), thus revealing the absence of any significant interaction.

\section{Conclusions}

A series of diiron complexes (2a-f) with a bridging functionalized allylidene ligand and ancillary cyclopentadienyl and carbonyl ligands has been prepared by addition of cyanide to vinyliminium precursors. This reaction is governed by intramolecular forces and steric factors, as elucidated by DFT calculations, resulting in full regio- and stereoselectivity. The products are fairly robust in aqueous solution and have been assessed for their antiproliferative activity, thus constituting a rare family of diorganoiron compounds investigated for possible pharmacological applications in cancer chemotherapy. The cytotoxicity of the complexes can be modulated varying the substituents on the allylidene moiety, and appears to overcome resistance mechanisms, since a comparable activity against cisplatin sensitive and cisplatin resistant cell lines was generally detected. This efficacy represents an improvement with respect to the behavior of the recently investigated diiron ionic parent compounds. ${ }^{20}$ The mode of action of the allylidene complexes may be very different from classical metal-based drugs, with limited interactions with DNA or BSA (used as a model protein). Instead, the antiproliferative activity of $\mathbf{2 b - f}$ is probably correlated to their favorable oxidation potential, leading to the generation of ROS and thus affecting the cellular redox balance.

\section{Experimental Section}




\section{Synthetic procedures and characterization of the compounds}

General details. Caution! potassium cyanide and tetrabutylammonium cyanide are highly toxic, and particular care should be taken to avoid direct contact with the skin; contact with acid releases toxic hydrogen cyanide gas. The preparation and the isolation of products were carried out under a $\mathrm{N}_{2}$ atmosphere using standard Schlenk techniques; once obtained, all the products were stored in air. Solvents were purchased from Merck and distilled before use under $\mathrm{N}_{2}$ from appropriate drying agents. Organic reactants (TCI Europe or Merck) were commercial products of the highest purity available. Compounds $[\mathbf{1 a - f}] \mathrm{CF}_{3} \mathrm{SO}_{3}{ }^{17}$ and $\left[\mathrm{Fe}_{2} \mathrm{Cp}_{2}(\mathrm{CO})_{2}(\mu-\mathrm{CO})\{\mu-\mathrm{CNMe}(2-\right.$-naphthyl $\left.)\}\right] \mathrm{CF}_{3} \mathrm{SO}_{3}{ }^{17}$ were prepared according to published procedures. Chromatography was carried out on deactivated alumina column (Sigma Aldrich, 4\% $w / w$ water). Infrared spectra of solutions were recorded on a Perkin Elmer Spectrum 100 FT-IR spectrometer with a $\mathrm{CaF}_{2}$ liquid transmission cell $\left(2300-1500 \mathrm{~cm}^{-1}\right.$ range). Infrared spectra of solid samples were recorded on a Perkin Elmer Spectrum One FT-IR spectrometer, equipped with a UATR sampling accessory (4000-400 $\mathrm{cm}^{-1}$ range). IR spectra were processed with Spectragryph software. ${ }^{32}$ NMR spectra were recorded at $298 \mathrm{~K}$ on a Bruker Avance II DRX400 instrument equipped with a BBFO broadband probe. Chemical shifts (expressed in parts per million) were referenced to the residual solvent peaks $\left({ }^{1} \mathrm{H},{ }^{13} \mathrm{C}\right) .{ }^{33} \mathrm{NMR}$ spectra were assigned with the assistance of ${ }^{1} \mathrm{H}-{ }^{13} \mathrm{C}$ ( $g s$-HSQC and $g s$-HMBC) correlation experiments. ${ }^{34} \mathrm{NMR}$ signals due to a second isomeric form (where it has been possible to detect them) are italicized. Carbon, hydrogen and nitrogen analyses were performed on a Vario MICRO cube instrument (Elementar). Gaschromatographic analysis was carried out on a Perkin Elmer Clarus 500 instrument, equipped with a column packed with molecular sieves $5 \mathrm{~A}$ and coupled to a thermal conductivity detector, using He at $\mathrm{p}$ $=5 \mathrm{~atm}$ as a gas carrier, at $120^{\circ} \mathrm{C}$. 
Synthesis of $\left[\mathrm{Fe}_{2} \mathrm{Cp}_{2}(\mathrm{CO})(\mu-\mathrm{CO})\left\{\mu-\eta^{1}: \eta^{3}-\mathrm{C}^{3}(\mathrm{Ph}) \mathrm{C}^{2} \mathrm{HC} \mathrm{C}^{1} \mathrm{~N}(\mathrm{Me})(2-\right.\right.$-naphthyl $\left.\left.)\right\}\right] \mathrm{CF}_{3} \mathrm{SO}_{3},[1 \mathrm{~g}] \mathrm{CF}_{3} \mathrm{SO}_{3}$ (Chart 1).

Chart 1. Structure of $[\mathbf{1 g}]^{+}$.

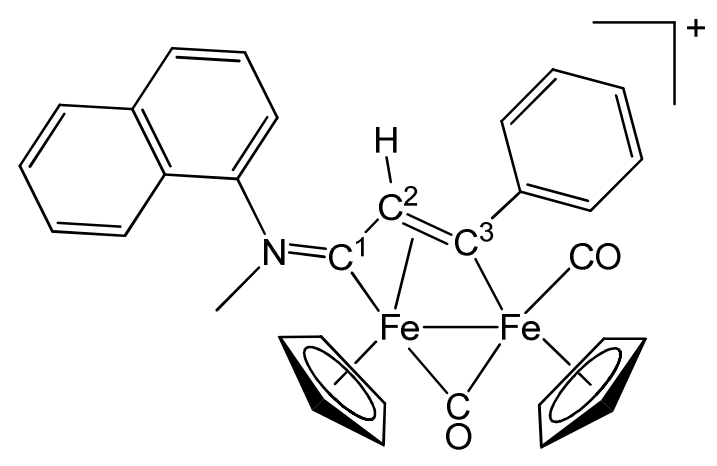

The title compound was prepared using a general literature procedure. ${ }^{17}\left[\mathrm{Fe}_{2} \mathrm{Cp}_{2}(\mathrm{CO})_{2}(\mu-\mathrm{CO})\{\mu\right.$ $\mathrm{CNMe}(2$-naphthyl $)\} \mathrm{CF}_{3} \mathrm{SO}_{3}(0.55 \mathrm{mmol})$ was dissolved into acetonitrile $(10 \mathrm{~mL})$ and treated with $\mathrm{Me}_{3} \mathrm{NO}$ (1.3 eq.). The resulting mixture was stirred for 1 hour, and the complete conversion into $\left[\mathrm{Fe}_{2} \mathrm{Cp}_{2}(\mathrm{CO})(\mu-\mathrm{CO})(\mathrm{NCMe})\{\mu-\mathrm{CNMe}(2-\right.$ naphthyl $\left.)\}\right] \mathrm{CF}_{3} \mathrm{SO}_{3}$ was checked by IR spectroscopy. The volatiles were removed under vacuum, thus the dark brown residue was dissolved into dichloromethane (ca. $20 \mathrm{~mL})$. The solution was treated with phenylacetylene $(0.65 \mathrm{mmol})$, and the mixture was stirred at room temperature for 48 hours, under a $\mathrm{N}_{2}$ atmosphere. The final mixture was charged on an alumina column. Elution with $\mathrm{CH}_{2} \mathrm{Cl}_{2}$ allowed the removal of unreacted alkyne and impurities, then the fraction corresponding to $[\mathbf{1 g}] \mathrm{CF}_{3} \mathrm{SO}_{3}$ was collected using $\mathrm{MeCN}$ as eluent. Removal of the solvent under reduced pressure afforded the product as an air-stable solid (yield 85\%). Anal. calcd. for $\mathrm{C}_{33} \mathrm{H}_{26} \mathrm{~F}_{3} \mathrm{Fe}_{2} \mathrm{NO}_{5} \mathrm{~S}: \mathrm{C}, 55.26 ; \mathrm{H}, 3.65 ; \mathrm{N}, 1.95$. Found: $\mathrm{C}, 55.12 ; \mathrm{H}, 3.79 ; \mathrm{N}, 2.03 . \mathrm{IR}\left(\mathrm{CH}_{2} \mathrm{Cl}_{2}\right): \tilde{\mathrm{v}} / \mathrm{cm}^{-1}=$ 1982vs (CO), 1813s $(\mu-\mathrm{CO}), 1649 \mathrm{~m}\left(\mathrm{C}^{2} \mathrm{C}^{1} \mathrm{~N}\right), 1627 \mathrm{~m}, 1597 \mathrm{w}$ (arom C-C). ${ }^{1} \mathrm{H}$ NMR $\left(\mathrm{CDCl}_{3}\right): \delta / \mathrm{ppm}=$ 8.18-7.15 (12 H, $\left.\mathrm{C}_{6} \mathrm{H}_{5}+\mathrm{C}_{10} \mathrm{H}_{7}\right) ; 5.32,5.07,4.97,4.88(\mathrm{~s}, 10 \mathrm{H}, \mathrm{Cp}) ; 4.44,3.44(\mathrm{~s}, 3 \mathrm{H}, \mathrm{NMe}) ; 3.73$ (s, $\left.1 \mathrm{H}, \mathrm{C}^{2} \mathrm{H}\right) . \mathrm{E} / \mathrm{Z}$ ratio $=9 .{ }^{13} \mathrm{C}\left\{{ }^{1} \mathrm{H}\right\}$ NMR $\left(\mathrm{CDCl}_{3}\right): \delta / \mathrm{ppm}=255.4,254.8(\mu-\mathrm{CO}) ; 230.3,228.9\left(\mathrm{C}^{1}\right)$; 
209.7 (CO); $205.2\left(\mathrm{C}^{3}\right) ; 155.6,143.6,140.8,132.8+129.9-119.0\left(\mathrm{C}_{6} \mathrm{H}_{5}+\mathrm{C}_{10} \mathrm{H}_{7}\right) ; 91.8,91.6,88.4$, $88.1(\mathrm{Cp}) ; 54.8\left(\mathrm{C}^{2}\right) ; 46.5(\mathrm{NMe})$.

Synthesis of $\left[\mathrm{Fe}_{2} \mathrm{Cp}_{2}(\mathrm{CO})(\mu-\mathrm{CO})\left\{\mu-\eta^{1}: \eta^{3}-\mathrm{C}^{3}(\mathrm{R}) \mathrm{C}^{2}\left(\mathrm{R}^{\prime}\right) \mathrm{C}^{1}(\mathrm{CN}) \mathrm{NMe}\right\}\right]\left(\mathrm{R}=\mathrm{CO}_{2} \mathrm{Me}, \mathrm{R}^{\prime}=\mathrm{CO}_{2} \mathrm{Me}\right.$, 2a; R = Ph, $\mathbf{R}^{\prime}=\mathbf{H}, 2 \mathrm{~b} ; \mathbf{R}=3-\mathrm{C}_{6} \mathrm{H}_{4} \mathrm{OH}, \mathbf{R}^{\prime}=\mathrm{H}, 2 \mathrm{c} ; \mathbf{R}=$ 3-thiophenyl, $\mathbf{R}^{\prime}=\mathbf{H}, 2 \mathrm{~d} ; \mathbf{R}=\mathrm{Me}, \mathbf{R}^{\prime}=\mathbf{H}$, 2e)

General procedure. A solution of $[\mathbf{1 a - e}] \mathrm{CF}_{3} \mathrm{SO}_{3}$ (ca. $\left.0.3 \mathrm{mmol}\right)$ in $\mathrm{CH}_{2} \mathrm{Cl}_{2}(20 \mathrm{~mL})$ was treated with tetrabutylammonium cyanide (1.2 eq.) and stirred at room temperature for 45 minutes. The mixture was then charged on an alumina column under nitrogen atmosphere, thus the fraction corresponding to 2a-e was collected. The solution was concentrated to ca. $5 \mathrm{~mL}$, and pentane (ca. $20 \mathrm{~mL}$ ) was added. Removal of the liquid under reduced pressure gave an air stable powdery solid.

$\left[\mathrm{Fe}_{2} \mathrm{Cp}_{2}(\mathrm{CO})(\mu-\mathrm{CO})\left\{\mu-\eta^{1}: \eta^{3}-\mathrm{C}^{3}\left(\mathrm{CO}_{2} \mathrm{Me}\right) \mathrm{C}^{2}\left(\mathrm{CO}_{2} \mathrm{Me}\right) \mathrm{C}^{1}(\mathrm{CN}) \mathrm{NMe} \mathrm{e}_{2}\right\}, 2 \mathrm{a}(\mathrm{Chart} 2)\right.$.

Chart 2. Structure of 2a.

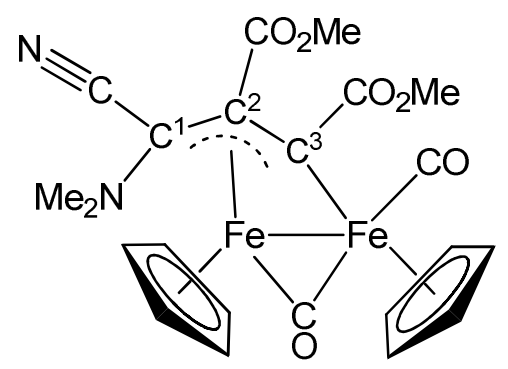

From $[1 \mathrm{a}] \mathrm{CF}_{3} \mathrm{SO}_{3}$. Red solid, yield $82 \%$. Eluent for chromatography: $\mathrm{CH}_{2} \mathrm{Cl}_{2}$. Anal. calcd. for $\mathrm{C}_{22} \mathrm{H}_{22} \mathrm{Fe}_{2} \mathrm{~N}_{2} \mathrm{O}_{6}: \mathrm{C}, 50.61 ; \mathrm{H}, 4.25 ; \mathrm{N}, 5.37$. Found: C, 50.52; H, 4.33; N, 5.29. IR $\left(\mathrm{CH}_{2} \mathrm{Cl}_{2}\right): \tilde{v} / \mathrm{cm}^{-1}=$ 2191w-m $(\mathrm{C} \equiv \mathrm{N}), 1977 \mathrm{vs}(\mathrm{CO}), 1804 \mathrm{~s}(\mu-\mathrm{CO}), 1720\left(\mathrm{CO}_{2} \mathrm{Me}\right) .{ }^{1} \mathrm{H} \mathrm{NMR}\left(\mathrm{CDCl}_{3}\right): \delta / \mathrm{ppm}=4.88,4.72$ $(\mathrm{s}, 10 \mathrm{H}, \mathrm{Cp}) ; 4.02,3.86\left(\mathrm{~s}, 6 \mathrm{H}, \mathrm{CO}_{2} \mathrm{Me}\right) ; 2.12,1.77\left(\mathrm{~s}, 6 \mathrm{H}, \mathrm{NMe}_{2}\right) .{ }^{13} \mathrm{C}\left\{{ }^{1} \mathrm{H}\right\} \mathrm{NMR}\left(\mathrm{CDCl}_{3}\right): \delta / \mathrm{ppm}=$ 
$260.6(\mu-\mathrm{CO}) ; 211.1(\mathrm{CO}) ; 184.6\left(\mathrm{C}^{3}\right) ; 179.7,170.9\left(\mathrm{CO}_{2} \mathrm{Me}\right) ; 130.2(\mathrm{C} \equiv \mathrm{N}) ; 89.2,88.5(\mathrm{Cp}) ; 84.6\left(\mathrm{C}^{2}\right)$; $57.1\left(\mathrm{C}^{1}\right) ; 53.2,52.4\left(\mathrm{CO}_{2} \mathrm{Me}\right) ; 48.3,40.8\left(\mathrm{NMe}_{2}\right)$.

\section{$\left[\mathrm{Fe}_{2} \mathrm{Cp}_{2}(\mathrm{CO})(\mu-\mathrm{CO})\left\{\mu-\eta^{1}: \eta^{3}-\mathrm{C}^{3}(\mathrm{Ph}) \mathrm{C}^{2} \mathrm{HC}^{1}(\mathrm{CN}) \mathrm{NMe}\right\}\right], 2 \mathrm{~b}(\mathrm{Chart} 3)$.}

Chart 3. Structure of $\mathbf{2 b}$.

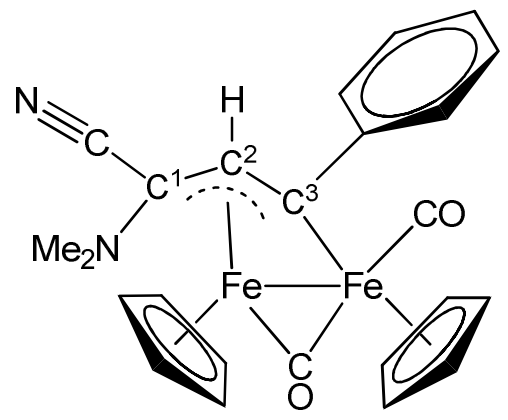

From $[\mathbf{1 b}] \mathrm{CF}_{3} \mathrm{SO}_{3}$. Dark-brown solid, yield $87 \%$. Eluent for chromatography: $\mathrm{CH}_{2} \mathrm{Cl}_{2}$. Anal. calcd. for $\mathrm{C}_{24} \mathrm{H}_{22} \mathrm{Fe}_{2} \mathrm{~N}_{2} \mathrm{O}_{2}:$ C, 59.79; H, 4.60; N, 5.81. Found: C, 59.62; H, 4.64; N, 5.71. IR $\left(\mathrm{CH}_{2} \mathrm{Cl}_{2}\right): \tilde{v} / \mathrm{cm}^{-1}=$ 2189w-m $(\mathrm{C} \equiv \mathrm{N}), 1970 \mathrm{vs}(\mathrm{CO}), 1787 \mathrm{~s}(\mu-\mathrm{CO}) .{ }^{1} \mathrm{H}$ NMR $\left(\mathrm{CDCl}_{3}\right): \delta / \mathrm{ppm}=7.63\left(\mathrm{~m}, 2 \mathrm{H}\right.$, meta- $\left.\mathrm{C}_{6} \mathrm{H}_{5}\right)$; $7.51\left(\mathrm{t}, 2 \mathrm{H}\right.$, ortho- $\left.\mathrm{C}_{6} \mathrm{H}_{5}\right) ; 7.36\left(\mathrm{t}, 1 \mathrm{H}\right.$, para- $\left.\mathrm{C}_{6} \mathrm{H}_{5}\right) ; 4.72,4.64(\mathrm{~s}, 10 \mathrm{H}, \mathrm{Cp}) ; 4.51\left(\mathrm{~s}, 1 \mathrm{H}, \mathrm{C}{ }^{2} \mathrm{H}\right) ; 2.39$, $1.87\left(\mathrm{~s}, 6 \mathrm{H}, \mathrm{NMe}_{2}\right) .{ }^{13} \mathrm{C}\left\{{ }^{1} \mathrm{H}\right\} \mathrm{NMR}\left(\mathrm{CDCl}_{3}\right): \delta / \mathrm{ppm}=264.7(\mu-\mathrm{CO}) ; 212.4(\mathrm{CO}) ; 200.5\left(\mathrm{C}^{3}\right) ; 159.2$ (ipso- $\left.\mathrm{C}_{6} \mathrm{H}_{5}\right) ; 127.9,127.5,125.6\left(\mathrm{C}_{6} \mathrm{H}_{5}\right) ; 120.8(\mathrm{C} \equiv \mathrm{N}) ; 89.3,85.9(\mathrm{Cp}) ; 81.9\left(\mathrm{C}^{2}\right) ; 64.8\left(\mathrm{C}^{1}\right) ; 49.6,42.0$ $\left(\mathrm{NMe}_{2}\right)$. Crystals suitable for X-ray analysis were obtained from a dichloromethane solution layered with pentane and stored at $-30^{\circ} \mathrm{C}$.

$\left[\mathrm{Fe}_{2} \mathrm{Cp}_{2}(\mathrm{CO})(\mu-\mathrm{CO})\left\{\mu-\eta^{1}: \eta^{3}-\mathrm{C}^{3}\left(3-\mathrm{C}_{6} \mathrm{H}_{4} \mathrm{OH}\right) \mathrm{C}^{2} \mathrm{HC}^{1}(\mathrm{CN}) \mathrm{NMe} \mathrm{e}_{2}\right\}\right], 2 \mathrm{c}(\mathrm{Chart} 4)$.

Chart 4. Structure of 2c. 


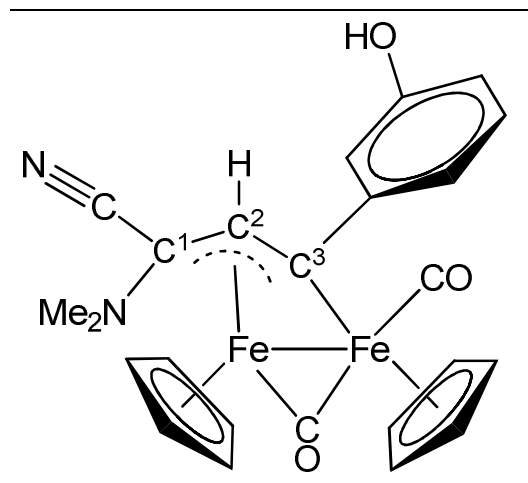

From $[\mathbf{1 c}] \mathrm{CF}_{3} \mathrm{SO}_{3}$. Brown solid, yield $72 \%$. Eluent for chromatography: $\mathrm{CH}_{2} \mathrm{Cl}_{2}$. Anal. calcd. for $\mathrm{C}_{24} \mathrm{H}_{22} \mathrm{Fe}_{2} \mathrm{~N}_{2} \mathrm{O}_{3}:$ C, 57.87; H, 4.45; N, 5.62. Found: C, 57.70; H, 4.51; N, 5.59. IR $\left(\mathrm{CH}_{2} \mathrm{Cl}_{2}\right): \tilde{v} / \mathrm{cm}^{-1}=$ 2190w-m $(\mathrm{C} \equiv \mathrm{N}), 1970 \mathrm{vs}(\mathrm{CO}), 1788 \mathrm{~s}(\mu-\mathrm{CO}), 1593 \mathrm{~m}$ (arom C-C). ${ }^{1} \mathrm{H}$ NMR $\left(\mathrm{CDCl}_{3}\right): \delta / \mathrm{ppm}=7.35$, 7.16, 6.84 (m, $\left.4 \mathrm{H}, \mathrm{C}_{6} \mathrm{H}_{4}\right) ; 5.81$ (br, $\left.1 \mathrm{H}, \mathrm{OH}\right) ; 4.72$, 4.66 (s, $\left.10 \mathrm{H}, \mathrm{Cp}\right) ; 4.51\left(\mathrm{~s}, 1 \mathrm{H}, \mathrm{C}^{2} \mathrm{H}\right) ; 2.37,1.84$ $(\mathrm{s}, 6 \mathrm{H}, \mathrm{NMe} 2) .{ }^{13} \mathrm{C}\left\{{ }^{1} \mathrm{H}\right\} \mathrm{NMR}\left(\mathrm{CDCl}_{3}\right): \delta / \mathrm{ppm}=263.6(\mu-\mathrm{CO}) ; 213.7(\mathrm{CO}) ; 200.7\left(\mathrm{C}^{3}\right) ; 160.8,156.8$ (ipso- $\left.\mathrm{C}_{6} \mathrm{H}_{4}+\mathrm{C}-\mathrm{OH}\right) ; 128.7,119.2,114.6,112.3\left(\mathrm{C}_{6} \mathrm{H}_{4}\right) ; 120.2(\mathrm{C} \equiv \mathrm{N}) ; 89.5,86.1(\mathrm{Cp}) ; 81.4\left(\mathrm{C}^{2}\right) ; 64.3$ $\left(\mathrm{C}^{1}\right) ; 48.9,41.5(\mathrm{NMe})$.

$\left[\mathrm{Fe}_{2} \mathrm{Cp}_{2}(\mathrm{CO})(\mu-\mathrm{CO})\left\{\mu-\eta^{1}: \eta^{3}-\mathrm{C}^{3}\left(3-\right.\right.\right.$ thiophenyl) $\left.\left.\mathrm{C}^{2} \mathrm{HC}^{1}(\mathrm{CN}) \mathrm{NMe}\right\}\right], 2 \mathrm{~d}$ (Chart 5).

Chart 5. Structure of 2d.

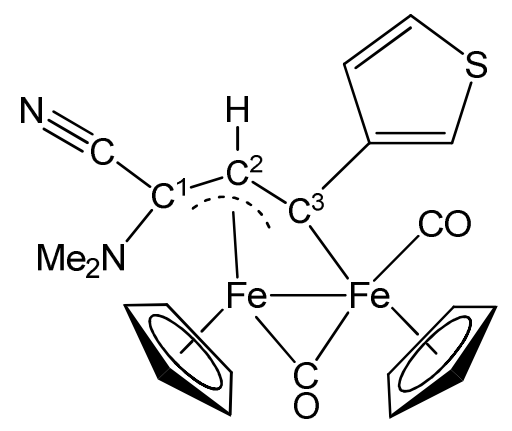

From $[\mathbf{1 d}] \mathrm{CF}_{3} \mathrm{SO}_{3}$. Dark-brown solid, yield $68 \%$. Eluent for chromatography: $\mathrm{Et}_{2} \mathrm{O} / \mathrm{CH}_{2} \mathrm{Cl}_{2} 1: 1 \mathrm{v} / \mathrm{v}$. Anal. calcd. for $\mathrm{C}_{22} \mathrm{H}_{20} \mathrm{Fe}_{2} \mathrm{~N}_{2} \mathrm{O}_{2} \mathrm{~S}$ : C, 54.13; H, 4.13; N, 5.74. Found: C, 54.02; H, 4.19; N, 5.61. IR 
$\left(\mathrm{CH}_{2} \mathrm{Cl}_{2}\right): \tilde{v} / \mathrm{cm}^{-1}=2190 \mathrm{w}-\mathrm{m}(\mathrm{C} \equiv \mathrm{N}), 1969 \mathrm{vs}(\mathrm{CO}), 1788 \mathrm{~s}(\mu-\mathrm{CO}), 1607 \mathrm{~m}$ (thiophenyl C-C). ${ }^{1} \mathrm{H}$ NMR $\left(\mathrm{CDCl}_{3}\right): \delta / \mathrm{ppm}=7.47,7.36,7.28\left(\mathrm{~m}, 3 \mathrm{H}, \mathrm{C}_{4} \mathrm{H}_{3} \mathrm{~S}\right) ; 4.69,4.64(\mathrm{~s}, 10 \mathrm{H}, \mathrm{Cp}) ; 4.56\left(\mathrm{~s}, 1 \mathrm{H}, \mathrm{C}{ }^{2} \mathrm{H}\right) ; 2.35$, $1.82\left(\mathrm{~s}, 6 \mathrm{H}, \mathrm{NMe}_{2}\right) .{ }^{13} \mathrm{C}\left\{{ }^{1} \mathrm{H}\right\} \mathrm{NMR}\left(\mathrm{CDCl}_{3}\right): \delta / \mathrm{ppm}=264.7(\mu-\mathrm{CO}) ; 212.5(\mathrm{CO}) ; 192.2\left(\mathrm{C}^{3}\right) ; 160.7$ (ipso- $\left.\mathrm{C}_{4} \mathrm{H}_{3} \mathrm{~S}\right) ; 129.6,125.1,117.6\left(\mathrm{C}_{4} \mathrm{H}_{3} \mathrm{~S}\right) ; 120.8(\mathrm{C} \equiv \mathrm{N}) ; 89.1,86.0(\mathrm{Cp}) ; 82.1\left(\mathrm{C}^{2}\right) ; 65.4\left(\mathrm{C}^{1}\right) ; 49.6$, 42.1 $\left(\mathrm{NMe}_{2}\right)$. Crystals suitable for X-ray analysis were obtained from a diethyl ether solution layered with pentane and stored at $-30^{\circ} \mathrm{C}$.

\section{$\left[\mathrm{Fe}_{2} \mathrm{Cp}_{2}(\mathrm{CO})(\mu-\mathrm{CO})\left\{\mu-\eta^{1}: \eta^{3}-\mathrm{C}^{3}(\mathrm{Me}) \mathrm{C}^{2} \mathrm{HC}^{1}(\mathrm{CN}) \mathrm{NMe}\right\}\right], 2 \mathrm{e}$ (Chart 6).}

Chart 6. Structure of $2 \mathrm{e}$.

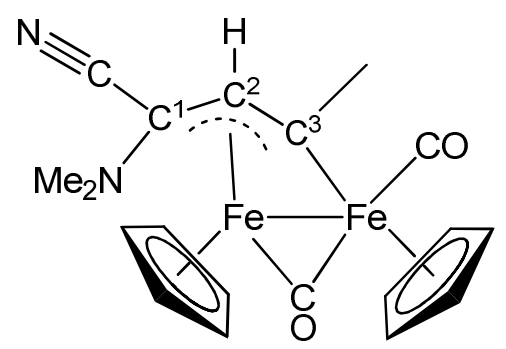

From $[1 \mathrm{e}] \mathrm{CF}_{3} \mathrm{SO}_{3}$. Dark-brown solid, yield $67 \%$. Eluent for chromatography: $\mathrm{Et}_{2} \mathrm{O}$. Anal. calcd. for $\mathrm{C}_{19} \mathrm{H}_{20} \mathrm{Fe}_{2} \mathrm{~N}_{2} \mathrm{O}_{2}:$ C, 54.33; H, 4.80; N, 6.67. Found: C, 54.21; H, 4.72; N, 6.75. IR $\left(\mathrm{CH}_{2} \mathrm{Cl}_{2}\right): \tilde{v} / \mathrm{cm}^{-1}=$ $2187 \mathrm{~m}(\mathrm{C} \equiv \mathrm{N}), 1966 \mathrm{vs}(\mathrm{CO}), 1786 \mathrm{~s}(\mu-\mathrm{CO}) .{ }^{1} \mathrm{H}$ NMR (acetone- $\left.\mathrm{d}_{6}\right): \delta / \mathrm{ppm}=5.07,4.55(\mathrm{~s}, 10 \mathrm{H}, \mathrm{Cp})$; $4.45\left(\mathrm{~s}, 1 \mathrm{H}, \mathrm{C}^{2} \mathrm{H}\right) ; 3.95\left(\mathrm{~s}, 3 \mathrm{H}, \mathrm{C}^{3} \mathrm{Me}\right) ; 2.25,1.70\left(\mathrm{~s}, 6 \mathrm{H}, \mathrm{NMe}_{2}\right) \cdot{ }^{13} \mathrm{C}\left\{{ }^{1} \mathrm{H}\right\} \mathrm{NMR}\left(\right.$ acetone- $\left.\mathrm{d}_{6}\right): \delta / \mathrm{ppm}=$ $264.0(\mu-\mathrm{CO}) ; 214.2(\mathrm{CO}) ; 201.6\left(\mathrm{C}^{3}\right) ; 120.3(\mathrm{C} \equiv \mathrm{N}) ; 88.5,86.0(\mathrm{Cp}) ; 82.2\left(\mathrm{C}^{2}\right) ; 65.8\left(\mathrm{C}^{1}\right) ; 48.5,41.7$ $\left(\mathrm{NMe}_{2}\right) ; 42.7\left(\mathrm{C}^{3} \mathrm{Me}\right)$. Crystals suitable for X-ray analysis were obtained from a dichloromethane solution layered with pentane and stored at $-30^{\circ} \mathrm{C}$.

\section{Synthesis of $\left[\mathrm{Fe}_{2} \mathrm{Cp} \mathrm{p}_{2}(\mathrm{CO})(\mu-\mathrm{CO})\left\{\mu-\eta^{1}: \eta^{3}-\mathrm{C}^{3}\left(4-\mathrm{C}_{6} \mathrm{H}_{4} \mathrm{CO}_{2} \mathrm{H}\right) \mathrm{C}^{2} \mathrm{HC}^{1}(\mathrm{CN}) \mathrm{NMe} \mathrm{e}_{2}\right\}\right.$, $2 \mathrm{f}$ (Chart 7$)$.}

Chart 7. Structure of $\mathbf{2 f}$. 


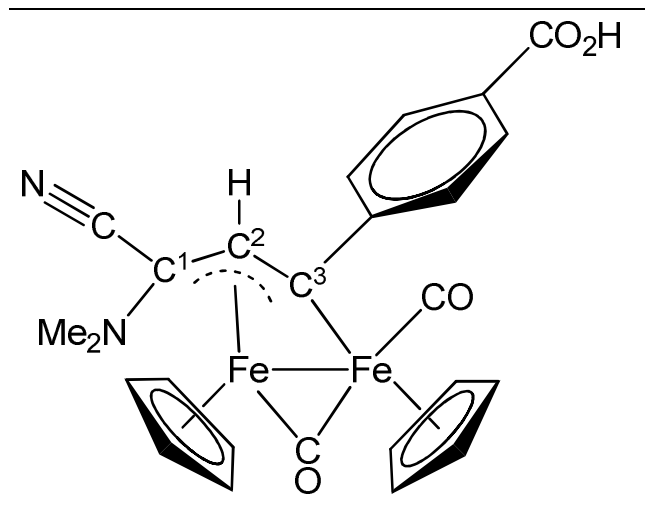

A solution of $[\mathbf{1 f}] \mathrm{CF}_{3} \mathrm{SO}_{3}(0.45 \mathrm{mmol})$ in $\mathrm{CH}_{3} \mathrm{OH}(12 \mathrm{~mL})$ was treated with potassium cyanide $(42 \mathrm{mg}$, $0.55 \mathrm{mmol}$ ) and stirred at room temperature for 1 hour. Solvent removal afforded a brown residue, which was dissolved in $\mathrm{CH}_{2} \mathrm{Cl}_{2}$ and filtered on a celite pad under nitrogen atmosphere. Solvent evaporation under reduced pressure afforded $2 \mathbf{f}$ as a brown powder (yield 63\%). Anal. calcd. for $\mathrm{C}_{25} \mathrm{H}_{22} \mathrm{Fe}_{2} \mathrm{~N}_{2} \mathrm{O}_{4}$ : C, 57.07; H, 4.21; N, 5.32. Found: C, 56.89; H, 4.23; N, 5.36. IR $\left(\mathrm{CH}_{2} \mathrm{Cl}_{2}\right): \tilde{v} / \mathrm{cm}^{-1}=$ 2189w-m $(\mathrm{C} \equiv \mathrm{N}), 1968 \mathrm{vs}(\mathrm{CO}), 1790 \mathrm{~s}(\mu-\mathrm{CO}), 1596 \mathrm{~m}-\mathrm{s}$ (arom C-C). IR (solid state): $\tilde{\mathrm{v}} / \mathrm{cm}^{-1}=2862 \mathrm{vw}$, 2823w, 2780w, 2185m (C $\equiv \mathrm{N}), 2113 \mathrm{~m}-\mathrm{br}, 1954 \mathrm{vs}(\mathrm{CO}), 1781 \mathrm{vs}(\mathrm{CO}), 1588 \mathrm{~s}, 1540 \mathrm{~m}-\mathrm{s}, 1386 \mathrm{vs}$, 1175w, 1156w, 1095m, 1035m-s, 946m, 863w-m, 831m, 798s, 755w-m, 733w, 715m-s, 703w, 661m. ${ }^{1} \mathrm{H}$ NMR $\left(\right.$ acetone- $\left.\mathrm{d}_{6}\right): \delta / \mathrm{ppm}=8.22,7.81\left(\mathrm{br}, 4 \mathrm{H}, \mathrm{C}_{6} \mathrm{H}_{4}\right) ; 4.86,4.81(\mathrm{~s}, 10 \mathrm{H}, \mathrm{Cp}) ; 4.46\left(\mathrm{~s}, 1 \mathrm{H}, \mathrm{C}^{2} \mathrm{H}\right)$; 2.33, $1.74\left(\mathrm{~s}, 6 \mathrm{H}, \mathrm{NMe}_{2}\right) .{ }^{13} \mathrm{C}\left\{{ }^{1} \mathrm{H}\right\}$ NMR (acetone-d $\left.\mathrm{d}_{6}\right): \delta / \mathrm{ppm}=263.4(\mu-\mathrm{CO}) ; 213.5(\mathrm{CO}) ; 199.6\left(\mathrm{C}^{3}\right)$; $170.3\left(\mathrm{CO}_{2} \mathrm{H}\right) ; 162.0\left(\right.$ ipso $\left.-\mathrm{C}_{6} \mathrm{H}_{4}\right) ; 132.8,129.5,127.3,126.3,123.1\left(\mathrm{C}_{6} \mathrm{H}_{4}\right) ; 120.3(\mathrm{C} \equiv \mathrm{N}) ; 89.6,86.3$ (Cp); $81.3\left(\mathrm{C}^{2}\right) ; 64.5\left(\mathrm{C}^{1}\right) ; 49.2,41.6\left(\mathrm{NMe}_{2}\right)$.

Synthesis of $\left[\mathrm{Fe}_{2} \mathrm{Cp}_{2}(\mathrm{CO})(\mu-\mathrm{CO})\left\{\mu-\eta^{1}: \eta^{3}-\mathrm{C}^{3}(\mathrm{Ph}) \mathrm{C}^{2} \mathrm{HC}(\mathrm{CN}) \mathrm{NMe}(2-n a p h t h y l)\right\}\right], 4$ (Chart 8).

Chart 8. Structure of 4. 


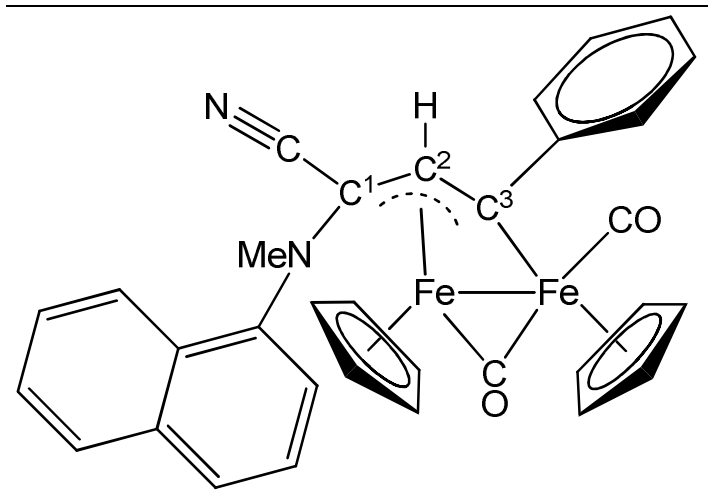

The title compound was prepared by using the procedure described for $\mathbf{2 a - e}$, starting from $[\mathbf{1 g}] \mathrm{CF}_{3} \mathrm{SO}_{3}$ (0.30 mmol). Dark-brown solid, yield 70\%. Eluent for chromatography: $\mathrm{Et}_{2} \mathrm{O}$. Anal. calcd. for $\mathrm{C}_{33} \mathrm{H}_{26} \mathrm{Fe}_{2} \mathrm{~N}_{2} \mathrm{O}_{2}:$ C, 66.70; H, 4.41; N, 4.71. Found: C, 66.55; H, 4.53; N, 4.76. IR $\left(\mathrm{CH}_{2} \mathrm{Cl}_{2}\right): \tilde{v} / \mathrm{cm}^{-1}=$ 2193w-m $(\mathrm{C} \equiv \mathrm{N}), 1979 \mathrm{vs}(\mathrm{CO}), 1790 \mathrm{~s}(\mu-\mathrm{CO}), 1629 \mathrm{~m}, 1598 \mathrm{~m}, 1508 \mathrm{~m}$ (arom C-C). ${ }^{1} \mathrm{H}$ NMR (acetone$\left.\mathrm{d}_{6}\right): \delta / \mathrm{ppm}=8.01-7.20\left(\mathrm{~m}, 12 \mathrm{H}, \mathrm{C}_{6} \mathrm{H}_{5}+\mathrm{C}_{10} \mathrm{H}_{7}\right) ; 4.96,4.76,5.00,4.75(\mathrm{~s}, 10 \mathrm{H}, \mathrm{Cp}) ; 5.33,4.97(\mathrm{~s}, 1 \mathrm{H}$, $\left.\mathrm{C}^{2} \mathrm{H}\right) ; 3.28,2.69(\mathrm{~s}, 3 \mathrm{H}, \mathrm{NMe})$. Isomer ratio $=1.4 .{ }^{13} \mathrm{C}\left\{{ }^{1} \mathrm{H}\right\}$ NMR (acetone- $\left.\mathrm{d}_{6}\right): \delta / \mathrm{ppm}=264.3$, 258.8( $\mu-\mathrm{CO}) ; 213.8,212.1(\mathrm{CO}) ; 201.4,199.3\left(\mathrm{C}^{3}\right)$; 159.5, 159.4 (ipso- $\mathrm{C}_{6} \mathrm{H}_{5}$ ); 149.2, 145.5 (ipso$\left.\mathrm{C}_{10} \mathrm{H}_{7}\right) ; 134.3-123.0\left(\mathrm{C}_{6} \mathrm{H}_{5}+\mathrm{C}_{10} \mathrm{H}_{7}\right) ; 120.2,118.8(\mathrm{C} \equiv \mathrm{N}) ; 91.2 ; 90.0,86.8,86.6(\mathrm{Cp}) ; 86.0,83.6\left(\mathrm{C}^{2}\right)$; 57.9, 57.0 $\left(\mathrm{C}^{1}\right) ; 47.6,42.0(\mathrm{NMe})$.

\section{Determination of partition coefficients $\left(\log P_{\text {ow }}\right)$ and stability in aqueous solutions.}

a) Determination of partition coefficients. Partition coefficients $\left(P_{\mathrm{ow}}\right.$; IUPAC: $K_{\mathrm{D}}$ partition constant $\left.{ }^{35}\right)$, defined as $P_{\mathrm{ow}}=\mathrm{c}_{\mathrm{org}} / \mathrm{c}_{\mathrm{aq}}$, where $\mathrm{c}_{\mathrm{org}}$ and $\mathrm{c}_{\mathrm{aq}}$ are the molar concentrations of the selected compound in the organic and aqueous phase respectively, were determined using the shake-flask method and UV-Vis measurements. ${ }^{36}$ All the operations were carried out at $21 \pm 1{ }^{\circ} \mathrm{C}$. De-ionized water and 1-octanol were mixed and vigorously stirred for 24 hours at room temperature to allow saturation of both phases, then separated by centrifugation and used for the following experiments. A solution of the selected Fe compound in octanol $(\mathrm{V}=20 \mathrm{~mL})$ was prepared and its $\mathrm{UV}-\mathrm{Vis}$ spectrum was recorded. An aliquot of 
the solution $\left(\mathrm{V}_{\text {org }}=3.0 \mathrm{~mL}\right)$ was then transferred into a test tube and the aqueous phase $\left(\mathrm{V}_{\mathrm{aq}}=3.0 \mathrm{~mL}\right)$ was added. The mixture was vigorously stirred for 12 hours and the resulting emulsion was centrifuged (2000 rpm, 15'), to separate the phases. Hence the UV-Vis spectrum of the organic phase was recorded. The partition coefficient was then calculated from $P_{\mathrm{ow}}=\frac{\mathrm{A}_{\mathrm{org}}}{\mathrm{A}_{0, \mathrm{org}}-\mathrm{A}_{\mathrm{org}}}$, where $\mathrm{A}_{0, \text { org }}$ and $\mathrm{A}_{\text {org }}$ are the absorbance values in the organic phase, respectively before and after mixing with the aqueous phase. ${ }^{36}$ UV-Vis measurements were carried out using $1 \mathrm{~cm}$ quartz cuvettes. The wavelength of the maximum absorption of each compound was used for UV-Vis quantification.

b) Stability in $\mathrm{D}_{2} \mathrm{O} /$ dmso- $_{6}$. Each compound (2a-f, ca. $3 \mathrm{mg}$ ) was dissolved in dmso- $\mathrm{d}_{6} / \mathrm{D}_{2} \mathrm{O}$ (ca. $2: 1$ v/v). The resulting solutions were analyzed by ${ }^{1} \mathrm{H}$ NMR spectroscopy and then heated at $37{ }^{\circ} \mathrm{C}$ for 72 hours. After cooling to room temperature, the final solutions were analyzed by ${ }^{1} \mathrm{H}$ NMR spectroscopy: the resonances of the starting compound were clearly recognized, together with minor signals due to non-identified species. 2a: ${ }^{1} \mathrm{H}$ NMR $\left(\mathrm{dmso}^{-} \mathrm{d}_{6} / \mathrm{D}_{2} \mathrm{O}\right), \delta / \mathrm{ppm}=5.01,4.70(\mathrm{~s}, 10 \mathrm{H}, \mathrm{Cp}), 3.87,3.74(\mathrm{~s}, 6$ $\left.\mathrm{H}, \mathrm{CO}_{2} \mathrm{Me}\right), 1.99,1.62\left(\mathrm{~s}, 6 \mathrm{H}, \mathrm{NMe}_{2}\right) .2 \mathbf{b}:{ }^{1} \mathrm{H}$ NMR $\left(\mathrm{dmso}_{6}-\mathrm{d}_{6} / \mathrm{D}_{2} \mathrm{O}\right), \delta / \mathrm{ppm}=7.64-7.31(\mathrm{Ph}), 5.14,4.87$ (s, $10 \mathrm{H}, \mathrm{Cp}), 4.53$ (s, $\left.1 \mathrm{H}, \mathrm{C}^{2} \mathrm{H}\right), 2.25,2.03$ (s, $6 \mathrm{H}, \mathrm{NMe}_{2}$ ). $2 \mathrm{c}:{ }^{1} \mathrm{H}$ NMR (dmso-d $\left.\mathrm{d}_{6} / \mathrm{D}_{2} \mathrm{O}\right), \delta / \mathrm{ppm}=7.28-$ $6.72\left(\mathrm{~m}, 4 \mathrm{H}, \mathrm{C}_{6} \mathrm{H}_{4}\right), 5.14,4.89(\mathrm{~s}, 10 \mathrm{H}, \mathrm{Cp}), 4.53\left(\mathrm{~s}, 1 \mathrm{H}, \mathrm{C}^{2} \mathrm{H}\right), 2.01,1.75\left(\mathrm{~s}, 6 \mathrm{H}, \mathrm{NMe}_{2}\right) .2 \mathrm{~d}:{ }^{1} \mathrm{H}$ NMR (dmso-d $\left.{ }_{6} / \mathrm{D}_{2} \mathrm{O}\right), \delta / \mathrm{ppm}=7.56,6.93\left(\mathrm{br}, 3 \mathrm{H}, \mathrm{C}_{4} \mathrm{H}_{3} \mathrm{~S}\right), 4.82,4.69(\mathrm{~s}, 10 \mathrm{H}, \mathrm{Cp}), 2.51,2.16(\mathrm{~s}, 6 \mathrm{H}$, $\left.\mathrm{NMe}_{2}\right) .2 \mathrm{e}:{ }^{1} \mathrm{H}$ NMR $\left(\mathrm{dmso}_{6} / \mathrm{D}_{2} \mathrm{O}\right), \delta / \mathrm{ppm}=5.01,4.50(\mathrm{~s}, 10 \mathrm{H}, \mathrm{Cp}), 4.02\left(\mathrm{~s}, 3 \mathrm{H}, \mathrm{C}^{3} \mathrm{Me}\right), 2.15,1.63$ $\left(\mathrm{s}, 6 \mathrm{H}, \mathrm{NMe}_{2}\right) .2 \mathrm{f}:{ }^{1} \mathrm{H}$ NMR $\left(\mathrm{dmso}_{6} / \mathrm{D}_{2} \mathrm{O}\right), \delta / \mathrm{ppm}=8.1,7.7\left(\mathrm{br}, 4 \mathrm{H}, \mathrm{C}_{6} \mathrm{H}_{4}\right), 5.02,4.78(\mathrm{~s}, 10 \mathrm{H}, \mathrm{Cp})$, $4.60\left(\mathrm{~s}, 1 \mathrm{H}, \mathrm{C}^{2} \mathrm{H}\right), 2.50,2.01\left(\mathrm{~s}, 6 \mathrm{H}, \mathrm{NMe}_{2}\right)$.

c) Stability in cell culture medium. The analyzed compound (2a-f, ca. $3 \mathrm{mg}$ ) was dissolved in dmso (3 $\mathrm{mL}$ ) in a glass tube, then RPMI-1640 medium with L-glutamine and sodium bicarbonate (ca. $1 \mathrm{~mL}$, Merck) was added. The resulting mixture was maintained at $37^{\circ} \mathrm{C}$ for 72 hours, then it was allowed to cool to room temperature. Dichloromethane (ca. $4 \mathrm{~mL}$ ) was added, and the mixture was vigorously 
shaken. An aliquot of the organic phase was analyzed by IR spectroscopy $\left(\mathrm{CH}_{2} \mathrm{Cl}_{2}\right.$ solution). The IR spectrum displayed the bands of $\mathbf{2 a - f}$ only.

d) CO release test. Compound $2 \mathbf{e}$ (ca. $15 \mathrm{mg}$ ) was dissolved in dmso (2 mL) in a glass tube, then RPMI-1640 medium with L-glutamine and sodium bicarbonate (ca. $4 \mathrm{~mL}$, Merck) was added. The tube was closed with a rubber septum, and the mixture was maintained at $37{ }^{\circ} \mathrm{C}$ for 72 hours, then it was allowed to cool to room temperature. An aliquot of the gas phase was analyzed by GC, evidencing the production of $\mathrm{CO}$.

\section{DFT calculations}

All geometries were optimized with ORCA 4.0.1.2, ${ }^{37}$ using the B97 functional ${ }^{38}$ in conjunction with a triple- $\zeta$ quality basis set (def2-TZVP). The dispersion corrections were taken into account using the Grimme D3-parametrized correction and the Becke - Jonhson damping to the DFT energy. ${ }^{39}$ All the structures were confirmed to be local energy minima (no imaginary frequencies). Thermodynamic parameters were computed at the same theoretical level.

\section{Electrochemistry}

Cyclic voltammetry measurements were performed with a PalmSens 4 instrument interfaced to a computer employing PSTrace5 electrochemical software. All potentials refer to FeCp 2 . HPLC grade DMSO (Sigma Aldrich) was stored under Ar over $3 \AA$ molecular sieves. $\left[\mathrm{N}^{\mathrm{n}} \mathrm{Bu}_{4}\right] \mathrm{PF}_{6}$ (Fluka, electrochemical grade) and $\mathrm{FeCp}_{2}$ (Fluka) were used without further purification. $\mathrm{CV}$ measurements were carried out under Ar using $0.1 \mathrm{M}\left[\mathrm{N}^{\mathrm{n}} \mathrm{Bu}_{4}\right] \mathrm{PF}_{6}$ in DMSO as the supporting electrolyte. The working and the counter electrodes consisted of a Pt disk and a Pt gauze, respectively, both sealed in a glass tube. $\mathrm{An} \mathrm{Ag} / \mathrm{AgCl}, \mathrm{KCl}$ sat electrode was employed as a reference. The three-electrode home- 
built cell was pre-dried by heating under vacuum and filled with argon. The Schlenk-type construction of the cell maintained anhydrous and anaerobic conditions. The solution of supporting electrolyte, prepared under argon, was introduced into the cell and the $\mathrm{CV}$ of the solvent was recorded. The analyte was then introduced and voltammograms were recorded. Under the present experimental conditions, the one-electron reduction of ferrocene occurred at $\mathrm{E}^{\circ}=+0.56 \mathrm{~V} v s \mathrm{Ag} / \mathrm{AgCl}, \mathrm{KCl}$ sat.

Infrared (IR) spectroelectrochemical measurements were carried out using an optically transparent thinlayer electrochemical (OTTLE) cell equipped with $\mathrm{CaF}_{2}$ windows, platinum mini-grid working and auxiliary electrodes and silver wire pseudo-reference electrode. ${ }^{40}$ During the microelectrolysis procedures, the electrode potential was controlled by a PalmSens4 instrument interfaced to a computer employing PSTrace5 electrochemical software. Argon-saturated DMSO solutions of the analyzed compound, containing $\left[\mathrm{N}^{\mathrm{n}} \mathrm{Bu}_{4}\right] \mathrm{PF}_{6} \quad 0.1 \mathrm{M}$ as the supporting electrolyte, were used. The in situ spectroelectrochemical experiments were performed by collecting IR spectra at fixed time intervals during the oxidation or reduction, obtained by continuously increasing or lowering the initial working potential at a scan rate of $2.0 \mathrm{mV} / \mathrm{sec}$.

\section{X-ray crystallography}

Crystal data and collection details for $\mathbf{2 b}, \mathbf{2 d}$ and $\mathbf{2 e}$ are reported in Table 4 . Data were recorded on a Bruker APEX II diffractometer equipped with a PHOTON100 detector using Mo-K $\alpha$ radiation. Data were corrected for Lorentz polarization and absorption effects (empirical absorption correction SADABS). ${ }^{41}$ The structures were solved by direct methods and refined by full-matrix least-squares based on all data using $F^{2}{ }^{42}$ Hydrogen atoms were fixed at calculated positions and refined by a riding model. All non-hydrogen atoms were refined with anisotropic displacement parameters, unless otherwise stated. The crystals of $\mathbf{2 b}$ are racemically twinned with refined Flack parameter $0.497(11)$. The crystals of $\mathbf{2 d}$ are pseudo-merohadrally twinned with twin matrix $\begin{array}{cllllllll}1 & 0 & 0 & 0 & -1 & 0 & 0 & 0 & -1\end{array}$ and refined 
batch factor $0.0776(7)$. The asymmetric unit of the unit cell of $\mathbf{2 d}$ contains two independent molecules with similar geometries and bonding parameters. The thiophenyl-substituents of $\mathbf{2} \mathbf{d}$ are disordered and, therefore, they have been split into two positions and refined isotropically. Restraints on the bonding distances and thermal parameters of the disordered groups have been applied (details are included in the res file embedded on the cif file).

Table 4. Crystal data and measurement details for $\mathbf{2 b}, \mathbf{2 d}$ and $\mathbf{2 e}$.

\begin{tabular}{|c|c|c|c|}
\hline & $2 b$ & $2 d$ & $2 e$ \\
\hline Formula & $\mathrm{C}_{24} \mathrm{H}_{22} \mathrm{Fe}_{2} \mathrm{~N}_{2} \mathrm{O}_{2}$ & $\mathrm{C}_{22} \mathrm{H}_{20} \mathrm{Fe}_{2} \mathrm{~N}_{2} \mathrm{O}_{2} \mathrm{~S}$ & $\mathrm{C}_{19} \mathrm{H}_{20} \mathrm{Fe}_{2} \mathrm{~N}_{2} \mathrm{O}_{2}$ \\
\hline FW & 482.13 & 488.16 & 420.07 \\
\hline $\mathrm{T}, \mathrm{K}$ & $100(2)$ & $294(2)$ & $293(2)$ \\
\hline$\lambda, \AA$ & 0.71073 & 0.71073 & 0.71073 \\
\hline Crystal system & Orthorhombic & Monoclinic & Monoclinic \\
\hline Space group & $P 2{ }_{1} 2_{1} 2_{1}$ & $P 2_{1} / c$ & $P 2_{1} / n$ \\
\hline$a, \AA$ & $8.8437(5)$ & $15.3950(15)$ & $9.693(3)$ \\
\hline$b, \AA$ & $13.1174(7)$ & $13.7089(13)$ & $16.641(4)$ \\
\hline$c, \AA$ & $17.3089(9)$ & $18.9602(19)$ & $10.735(3)$ \\
\hline$\beta,^{\circ}$ & 90 & $90.432(3)$ & $93.069(11)$ \\
\hline Cell Volume, $\AA^{3}$ & 2007.94(19) & $4001.4(7)$ & $1729.2(8)$ \\
\hline Z & 4 & 8 & 4 \\
\hline$D_{c}, \mathrm{~g} \cdot \mathrm{cm}^{-3}$ & 1.595 & 1.621 & 1.614 \\
\hline$\mu, \mathrm{mm}^{-1}$ & 1.469 & 1.576 & 1.692 \\
\hline$F(000)$ & 992 & 2000 & 864 \\
\hline Crystal size, mm & $0.23 \times 0.19 \times 0.15$ & $0.16 \times 0.14 \times 0.13$ & $0.15 \times 0.13 \times 0.12$ \\
\hline$\theta$ limits, ${ }^{\circ}$ & 1.948-27.998 & $1.698-26.440$ & 2.260-24.999 \\
\hline $\begin{array}{l}\text { Reflections } \\
\text { collected }\end{array}$ & 30044 & 54167 & 15290 \\
\hline $\begin{array}{l}\text { Independent } \\
\text { reflections }\end{array}$ & $4836\left[R_{\text {int }}=0.0210\right]$ & $8214\left[R_{\text {int }}=0.0422\right]$ & $3055\left[R_{\text {int }}=0.1106\right]$ \\
\hline $\begin{array}{l}\text { Data / restraints } \\
\text { /parameters }\end{array}$ & $4836 / 0 / 274$ & 8214 / 252/ 574 & 3055 / 0 / 229 \\
\hline $\begin{array}{l}\text { Goodness on fit } \\
\text { on } \mathrm{F}^{2}\end{array}$ & 1.158 & 1.046 & 1.179 \\
\hline$R_{1}(I>2 \sigma(I))$ & 0.0169 & 0.0532 & 0.0928 \\
\hline$w R_{2}$ (all data) & 0.0443 & 0.1237 & 0.2909 \\
\hline $\begin{array}{l}\text { Largest diff. peak } \\
\text { and hole, e } \AA^{-3}\end{array}$ & $0.236 /-0.406$ & $1.607 /-1.662$ & $2.457 /-1.213$ \\
\hline
\end{tabular}




\section{Cell culture and cytotoxicity studies}

Human ovarian carcinoma (A2780 and A2780cisR) cell lines were obtained from the European Collection of Cell Cultures. The human embryonic kidney (HEK-293) cell line was obtained from ATCC (Sigma, Buchs, Switzerland). Penicillin streptomycin, RPMI 1640 GlutaMAX (where RPMI = Roswell Park Memorial Institute), and DMEM GlutaMAX media (where DMEM = Dulbecco's modified Eagle medium) were obtained from Life Technologies, and fetal bovine serum (FBS) was obtained from Sigma. The cells were cultured in RPMI 1640 GlutaMAX (A2780 and A2780cisR) and DMEM GlutaMAX (HEK-293) media containing 10\% heat-inactivated FBS and 1\% penicillin streptomycin at $37{ }^{\circ} \mathrm{C}$ and $\mathrm{CO}_{2}(5 \%)$. The A2780cisR cell line was routinely treated with cisplatin $(2$ $\mu \mathrm{M})$ in the media to maintain cisplatin resistance. The cytotoxicity was determined using the $3-(4,5-$ dimethyl 2-thiazolyl)-2,5-diphenyl-2H-tetrazolium bromide (MTT) assay. ${ }^{43}$ Cells were seeded in flatbottomed 96-well plates as a suspension in a prepared medium (100 $\mu \mathrm{L}$ aliquots and approximately 4300 cells/well) and preincubated for 24 hours. Stock solutions of compounds were prepared in DMSO and were diluted in medium. The solutions were sequentially diluted to give a final DMSO concentration of $0.5 \%$ and a final compound concentration range $(0-200 \mu \mathrm{M})$. Cisplatin and RAPTA-C were tested as a positive $(0-100 \mu \mathrm{M})$ and negative $(200 \mu \mathrm{M})$ controls respectively. The compounds were added to the preincubated 96-well plates in $100 \mu \mathrm{L}$ aliquots, and the plates were incubated for a further 72 hours. MTT ( $20 \mu \mathrm{L}, 5 \mathrm{mg} / \mathrm{mL}$ in Dulbecco's phosphate buffered saline) was added to the cells, and the plates were incubated for a further $4 \mathrm{~h}$. The culture medium was aspirated and the purple formazan crystals, formed by the mitochondrial dehydrogenase activity of vital cells, were dissolved in DMSO (100 $\mu \mathrm{L} /$ well). The absorbance of the resulting solutions, directly proportional to the number of surviving cells, was quantified at $590 \mathrm{~nm}$ using a SpectroMax M5e multimode microplate reader (using SoftMax Pro software, version 6.2.2). The percentage of surviving cells was calculated from the 
absorbance of wells corresponding to the untreated control cells. The reported $\mathrm{IC}_{50}$ values are based on the means from two independent experiments, each comprising four tests per concentration level.

\section{ROS assessment}

The intracellular increase of reactive oxygen species (ROS) upon treatment with the analyzed complexes was measured by using the DCFH-DA $\left(2^{\prime}, 7^{\prime}\right.$-dichlorodihydrofluorescein diacetate, Sigma Aldrich) assay, based on cellular uptake of the non-fluorescent diacetate following deacetylation by esterases $\left(2^{\prime}, 7^{\prime}\right.$-dichlorodihydrofluorescein, DCFH) and oxidation to the fluorescent dichlorofluorescein $\left(2^{\prime}, 7^{\prime}\right.$-dichloro-fluorescein, DCF). ${ }^{44}$ A2 280 cells were seeded at concentration of $4 \cdot 10^{4}$ cells $/$ well/90 $\mu \mathrm{L}$ of complete growth medium into 96-well plates and allowed to proliferate for 24 hours. Then cells were treated following manufacturer protocol. Briefly, the culture medium was supplemented with 100 $\mu \mathrm{L}$ of the fluorogenic probe solution and cells were incubated under standard tissue culture conditions of $5 \% \mathrm{CO}_{2}$ at $37{ }^{\circ} \mathrm{C}$. After 1 hour, cells were exposed with a final concentration of $50 \mu \mathrm{M}$ of the tested compounds and maintained at $5 \% \mathrm{CO}_{2}$ at $37{ }^{\circ} \mathrm{C}$; the same concentration of $\mathrm{H}_{2} \mathrm{O}_{2}$ was used as a positive control. Stock solutions of compounds were prepared as described above; cells incubated with DMSO at a concentration of $0.5 \%$ in supplemented RPMI were used as control. The fluorescence was measured up to 24 hours with an excitation wavelength of $485 \mathrm{~nm}$ and with a $535 \mathrm{~nm}$ emission filter by Multilabel Counter (PerkinElmer, Waltham, USA). The ROS assessments were conducted on triplicate and the data were expressed as mean \pm SD. Statistical differences were analyzed using one-way analysis of variance (ANOVA) and a Tukey test was used for post hoc analysis. A p-value $<0.05$ was considered statistically significant.

\section{DNA and BSA binding studies}


Double stranded DNA was the B-helix from calf thymus (supplied as highly polymerized sodium salt from Merck, abbreviated as DNA in the text). Ethidium bromide $(\mathrm{EtBr}$, purity $>98 \%$ ) was from Merck. DNA was sonicated to reduce its length to ca. 500 base pairs following an already published procedure. ${ }^{45}$ The molar concentration of DNA $\left(\mathrm{C}_{\mathrm{DNA}}, \varepsilon_{260 \mathrm{~nm}}=13,200 \mathrm{M}^{-1} \mathrm{~cm}^{-1}\right.$ for concentrations expressed in base pairs), $\operatorname{EtBr}\left(\mathrm{C}_{\mathrm{EB}}, \varepsilon_{480 \mathrm{~nm}}=5,700 \mathrm{M}^{-1} \mathrm{~cm}^{-1}\right)$ and $\mathrm{BSA}\left(\mathrm{C}_{\mathrm{BSA}}, \varepsilon_{278 \mathrm{~nm}}=44,000 \mathrm{M}^{-1} \mathrm{~cm}^{-1}\right)$ were determined spectrophotometrically. Solutions of $\mathbf{2 b}$ were prepared by weighting appropriate amounts of the solid and dissolving them in DMSO (3.3 $\mathrm{mM}$ stock solution). Ultra-pure water (Sartorius) was the reaction medium, whereas $2.5 \mathrm{mM} \mathrm{NaCac}$ (sodium cacodylate) aqueous buffer was used to maintain $\mathrm{pH}=7.0 \mathrm{NaCl} 0.1 \mathrm{M}$ was added to reach physiological conditions in protein studies. $\mathrm{NaCl}$ was not added in the case of DNA, to favor possible $2 \mathbf{b} / \mathrm{DNA}$ interaction by increasing electrostatic attraction between the oppositely charged partners. Absorbance measurements were performed using a Shimadzu UV-2450 spectrophotometer, allowing temperature control $\left( \pm 0.1^{\circ} \mathrm{C}\right)$. During the spectrophotometric titration, equal amounts of the titrant (DNA) were directly added to both sample and reference cuvettes. This differential procedure enables the DNA contribution to the spectrum to be experimentally subtracted. The precise and accurate addition of volumes as small as $0.164 \mu \mathrm{L}$ was performed with a Hamilton syringe connected to a Mitutoyo micrometric screw. Fluorescence measurements were performed on a Perkin Elmer LS55 instrument (temperature \pm 0.1 $\left.{ }^{\circ} \mathrm{C}\right)$. In EtBr/DNA exchange experiments, DNA was saturated with EtBr according to a documented procedure $^{46}$ i.e. until the end of the fluorescence emission increase at the excitation/emission wavelength selective for the EtBr/DNA intercalated complex $\left(\lambda_{\mathrm{ex}}=520 \mathrm{~nm}, \lambda_{\mathrm{em}}=595 \mathrm{~nm}\right)$. Subsequently, increasing amounts of $\mathbf{2 b}$ stock solution were added to the EtBr/DNA mixture. For the $\mathbf{2 b} /$ BSA fluorescence titrations, a $\mathbf{2 b}$ solution $\left(5.05 \times 10^{-5} \mathrm{M}\right.$ in DMSO) was added to $6.02 \times 10^{-7} \mathrm{M}$ BSA solution $\left(\lambda_{\mathrm{ex}}=280 \mathrm{~nm}, \lambda_{\mathrm{em}}=345 \mathrm{~nm}\right)$. For both EtBr displacement and BSA titration, blank tests were 
carried out by adding DMSO to the sample cell, in order to quantify fluorescence changes due to dilution/solvent effects.

\section{Acknowledgements}

We gratefully thank the University of Pisa (Fondi di Ateneo 2018) and the Swiss National Science Foundation for financial support.

The authors declare no competing financial interests.

\section{Supporting Information Available}

DFT structures; cyclic voltammograms; details of DNA and BSA binding studies; ${ }^{1} \mathrm{H}$ and ${ }^{13} \mathrm{C}$ NMR spectra of products (most of residual peaks refer to solvent or water). CCDC reference numbers 1948219 (2b), 1948220 (2d) and 1948221 (2e) contain the supplementary crystallographic data for the X-ray studies reported in this paper. These data can be obtained free of charge at www.ccdc.cam.ac.uk/conts/retrieving.html (or from the Cambridge Crystallographic Data Centre, 12, Union Road, Cambridge CB2 1EZ, UK; fax: (internat.) +44-1223/336-033; e-mail: deposit@ccdc.cam.ac.uk).

\section{References}

1 a) Barry, N. P. E.; Sadler, P. J. Exploration of the medical periodic table: towards new targets. Chem. Commun. 2013, 49, 5106-5131. b) Lainé, A.-L.; Passirani, C. Novel metal-based anticancer drugs: a new challenge in drug delivery. Curr. Opin. Pharmacol. 2012, 12, 420-426. c) Jungwirth, U.; Kowol, C. R.; Keppler, B. K.; Hartinger, C. G.; Berger, W.; Heffeter, P. Anticancer activity of metal complexes: involvement of redox processes. Antioxid Redox Signal. 2011, 15, 1085-1127. (d) Marloye, M.; Berger, G.; 
Gelbcke, M.; Dufrasne, F. A survey of the mechanisms of action of anticancer transition metal complexes. Future Med. Chem. 2016, 8, 2263-2286. e) Gasser, G.; Metzler-Nolte, N. The potential of organometallic complexes in medicinal chemistry. Curr. Opinion Chem. Biol. 2012, 16, 84-91.

2 a) Apps, M. G.; Choi, E. H. Y.; Wheate, N. J. The state-of-play and future of platinum drugs. EndocrineRelated Cancer 2015, 22, R219-R233. b) Gibson, D. The mechanism of action of platinum anticancer agents—what do we really know about it? Dalton Trans., 2009, 10681-10689. c) Johnstone, T. C.; Suntharalingam, K.; Lippard, S. J. The Next Generation of Platinum Drugs: Targeted Pt(II) Agents, Nanoparticle Delivery, and Pt(IV) Prodrugs. Chem. Rev. 2016, 116, 3436 - 3486. d) Raudenska, M.; Balvan, J.; Fojtu, M.; Gumulec, J.; Masarik, M. Unexpected therapeutic effects of cisplatin. Metallomics, $2019,11,1182-1199$.

3 a) Oun, R.; Moussa, Y. E.; Wheate, N. J. The side effects of platinum-based chemotherapy drugs: a review for chemists. Dalton Trans. 2018, 47, 6645-6653. b) Min, Y.; Mao, C.-Q.; Chen, S.; Ma, G.; Wang, J.; Liu, Y. Combating the Drug Resistance of Cisplatin Using a Platinum Prodrug Based Delivery System. Angew. Chem. 2012, 124, 6846-6851. c) Siddik, Z. H. Cisplatin: mode of cytotoxic action and molecular basis of resistance. Oncogene 2003, 22, 7265-7279. d) Dasari, S.; Tchounwou, P. B. Cisplatin in cancer therapy: molecular mechanisms of action. Eur. J. Pharmacol. 2014, 740, 364-378. e) Kartalou, M.; Essigmann, J. M. Mechanisms of resistance to cisplatin. Mutat. Res. 2001, 478, 23-43.

4 Selected recent references: a) Zhang, P.; Sadler, P. J. Advances in the design of organometallic anticancer complexes. J. Organomet. Chem. 2017, 839, 5-14. b) Adams, M.; Hanif, M.; Hartinger, C. G. Ruthenium Anticancer Agents-From Cisplatin Analogues to Rational Drug Design. Encyclopedia of Inorganic and Bioinorganic Chemistry, 2017, Wiley Ed. c) Štarha, P.; Trávníček, Z. Non-platinum complexes containing releasable biologically active ligands. Coord. Chem. Rev. 2019, 395, 130-145. d) Santini, C.; Pellei, M.; Gandin, V.; Porchia, M.; Tisato, F.; Marzano, C. Advances in Copper Complexes as Anticancer Agents. Chem. Rev. 2014, 114, 815-862. e) Alam, M. N.; Huq, F. Comprehensive review on tumour active palladium compounds and structure-activity relationships. Coord. Chem. Rev. 2016, 316, 36-67. f) Nazarov, A. A.; Hartinger, C. G.; Dyson, P. J. Opening the lid on piano-stool complexes: An account of 
ruthenium(II)-arene complexes with medicinal applications. J. Organomet. Chem. 2014, 751, 251-260. g) Rilak Simovica, A.; Masnikosa, R.; Bratsos, I.; Alessio, E. Chemistry and reactivity of ruthenium(II) complexes: DNA/protein binding mode and anticancer activity are related to the complex structure. Coord. Chem. Rev. 2019, 398, 113011. h) Zou, T.; Lum, C. T.; Lok, C.-N.; Zhang, J.-J.; Che, C.-M. Chemical biology of anticancer gold(iii) and gold(i) complexes. Chem. Soc. Rev., 2015, 44, 8786-8801. i) Lazarevic, T.; Rilak, A.; Bugarcic, Z. D. Platinum, palladium, gold and ruthenium complexes as anticancer agents: Current clinical uses, cytotoxicity studies and future perspectives. Eur. J. Med. Chem. 2017, 142, 8-31.

5 a) Bratsos, I.; Gianferrara, T.; Alessio, E.; Hartinger, C. G.; Jakupec, M. A.; Keppler, B. K. Ruthenium and Other Non-Platinum Anticancer Compounds, in Bioinorganic Medicinal Chemistry, ed. E. Alessio, WileyVCH, Weinheim, 2011, 151-174. b) Alberto, R.; Biot, C.; Casini, A.; Dive, D.; Dyson, P. J.; Gibaud, S.; Habtermariam, A.; Hartinger, C. G.; Hillard, E. A.; Hogan, M.; Jaouen, G.; Mann, B. E.; Meggers, E.; Mulcahy, S. P.; Nazarov, A. A.; Metzler-Nolte, N.; Pizarro, A. M.; Sadler, P. J.; Tacke, M.; Vessieres, A. Topics in Organometallic Chemistry, 2010, Vol. 32.

6 Kaim, W.; Schwederski, B.; Klein, A. "Bioinorganic Chemistry: Inorganic Elements in the Chemistry of Life", 2nd Edition, Wiley 2013.

7 a) Astruc, D. Why is Ferrocene so Exceptional? Eur. J. Inorg. Chem. 2017, 6-29. b) Werner, H. At least 60 years of ferrocene: the discovery and rediscovery of the sandwich complexes. Angew. Chem. Int. Ed. 2012, 51, 6052-6058. c) Ali Larik, F.; Saeed, A.; Fattah, T. A.; Muqadar, U.; Channar, P. A. Recent advances in the synthesis, biological activities and various applications of ferrocene derivatives. Appl. Organomet. Chem. 2016, 31, 1-22.

8 a) Patra, M.; Gasser, G. The medicinal chemistry of ferrocene and its derivatives. Nat. Rev. Chem. 2017, 1, 1-12. b) Sansook, S.; Storm, H.-H.; Ocasio, C.; Spencer, J. Ferrocenes in medicinal chemistry; a personal perspective. J. Organomet. Chem. 2020, 905, 121017. c) Wani, W. A.; Baig, U.; Shreaz, S.; Shiekh, R. A.; Iqbal, P. F.; Jameel, E.; Ahmad, A.; Mohd-Setapar, S. H.; Mushtaque, M.; Hun, L. T. Recent advances in iron complexes as potential anticancer agents. New J. Chem., 2016, 40, 1063-1090.

9 Jaouen, G.; Vessiéres, A.; Top, S. Ferrocifen type anti cancer drugs. Chem. Soc. Rev., 2015, 44, 8802-8817. 
10 a) Wang, Y.; Dansette, P. M.; Pigeon, P.; Top, S.; McGlinchey, M. J.; Mansuy, D.; Jaouen, G. A new generation of ferrociphenols leads to a great diversity of reactive metabolites, and exhibits remarkable antiproliferative properties. Chem. Sci., 2018, 9, 70-78. b) Leonidova, A.; Anstaett, P.; Pierroz, V.; Mari, C.; Spingler, B.; Ferrari, S.; Gasser, G. Induction of Cytotoxicity through Photorelease of Aminoferrocene. Inorg. Chem. 2015, 54, 9740-9748. c) Ocasio, C. A.; Sansook, S.; Jones, R.; Roberts, J. M.; Scott, T. G.; Tsoureas, N.; Coxhead, P.; Guille, M.; Tizzard, G. J.; Coles, S. J.; Hochegger, H.; Bradner, J. E.; Spencer, J. Pojamide: An HDAC3-Selective Ferrocene Analogue with Remarkably Enhanced Redox-Triggered Ferrocenium Activity in Cells. Organometallics 2017, 36, 3276-3283.

11 a) Gong, G.; Cao, Y.; Wang, F.; Zhao, G. Planar Chiral Ferrocene Cyclopalladated Derivatives Induce Caspase-Dependent Apoptosis and Antimetastasis in Cancer Cells. Organometallics 2018, 37, 1103-1113. b) Reshetnikov, V.; Daum, S.; Mokhir, A. Cancer-Specific, Intracellular, Reductive Activation of Anticancer PtIV Prodrugs. Chem. Eur. J. 2017, 23, 5678 - 5681. c) Nieto, D.; Bruña, S.; Gonzàlez-Vadillo, A. M.; Perles, J.; Carrillo-Hermosilla, F.; Antiñolo, A.; Padròn, J. M.; Plata, G. B.; Cuadrado, I. Catalytically Generated Ferrocene-Containing Guanidines as Efficient Precursors for New Redox-Active Heterometallic Platinum(II) Complexes with Anticancer Activity. Organometallics 2015, 34, 5407-5417. d) Mu, C.; Chang, S. W.; Prosser, K. E.; Leung, A. W. Y.; Santacruz, S.; Jang, T.; Thompson, J. R.; Yapp, D. T. T.; Warren, J. J.; Bally, M. B.; Beischlag, T. V.; Walsby, C. J. Induction of Cytotoxicity in Pyridine Analogues of the Anti-metastatic Ru(III) Complex NAMI-A by Ferrocene Functionalization. Inorg. Chem. 2016, 55, 177-190. e) Reshetnikov, V.; Arkhypov, A.; Reddy Julakanti, P.; Mokhir, A. A cancer specific oxaliplatin-releasing Pt(iv)-prodrug. Dalton Trans., 2018, 47, 6679-6682. f) Mu, C.; Prosser, K. E.; Harrypersad, S.; MacNeil, G. A.; Panchmatia, R.; Thompson, J. R.; Sinha, S.; Warren, J. J.; Walsby, C. J. Activation by Oxidation: Ferrocene-Functionalized $\mathrm{Ru}(\mathrm{II})$-Arene Complexes with Anticancer, Antibacterial, and Antioxidant Properties. Inorg. Chem. 2018, 57, 15247-15261.

12 a) Pilon, A.; Gírio, P.; Nogueira, G.; Avecilla, F.; Adams, H.; Lorenzo, J.; Garcia, M. H.; Valente, A. New iron cyclopentadienyl complexes bearing different phosphane co-ligands: Structural factors vs. cytotoxicity. J. Organomet. Chem. 2017, 852, 34-42. b) Florindo, P. R.; Pereira, D. M.; Borralho, P. M.; Rodrigues, C. 
M. P.; Piedade, M. F. M.; Fernandes, A. C. Cyclopentadienyl-Ruthenium(II) and Iron(II) Organometallic Compounds with Carbohydrate Derivative Ligands as Good Colorectal Anticancer Agents. J. Med. Chem. 2015, 58, 4339-4347. c) Valente, A.; Santos, A. M.; Côrte-Real, L.; Robalo, M. P.; Moreno, V.; FontBardia, M.; Calvet, T.; Lorenzo, J.; Garcia, M. H. New iron(II) cyclopentadienyl derivative complexes: Synthesis and antitumor activity against human leukemia cancer cells. J. Organomet. Chem. 2014, 756, 5260. d) Gonçalves, A. C.; Morais, T. S.; Robalo, M. P.; Marques, F.; Avecilla, F.; Matos, C. P.; Santos, I.; Tomaz, A. I.; Garcia, M. H. Important cytotoxicity of novel iron(II) cyclopentadienyl complexes with imidazole based ligands. J. Inorg. Biochem. 2013, 129, 1-8.

13 a) García, M. E.; García-Vivó, D.; Ramos, A.; Ruiz, M. A. Phosphinidene-bridged binuclear complexes. Coord. Chem. Rev. 2017, 330, 1-36. b) Busetto, L.; Maitlis, P. M.; Zanotti, V. Bridging vinylalkylidene transition metal complexes. Coord. Chem. Rev. 2010, 254, 470-486. c) Tong, P.; Yang, D.; Li, Y.; Wang, B.; Qu, J. Hydration of Nitriles to Amides by Thiolate-Bridged Diiron Complexes. Organometallics 2015, 34, 3571-3576. d) Mazzoni, R.; Salmi, M.; Zanotti, V. C-C Bond Formation in Diiron Complexes. Chem. Eur. J. 2012, 18, 10174-10194. e) Lang, P.; Schwalbe, M. Pacman Compounds: From Energy Transfer to Cooperative Catalysis. Chem. Eur. J. 2017, 23, 17398-17412.

14 (a) Hirschhäuser, C.; Velcicky, J.; Schlawe, D.; Hessler, E.; Majdalani, A.; Neudçrfl, J.-M.; Prokop, A.; Wieder, T.; Schmalz, H.-G. Nucleoside Analogues with a 1,3-Diene-Fe(CO)3 Substructure: Stereoselective Synthesis, Configurational Assignment, and Apoptosis-Inducing Activity. Chem. Eur. J. 2013, 19, 1301713029. (b) Cingolani, A.; Zanotti, V.; Zacchini, S.; Massi, M.; Simpson, P. V.; Maheshkumar Desai, N.; Casari, I.; Falasca, M.; Rigamonti, R.; Mazzoni, R. Synthesis, reactivity and preliminary biological activity of iron $(0)$ complexes with cyclopentadienone and amino-appended N-heterocyclic carbene ligands. Appl. Organomet. Chem., 2019, 33, e4779. (c) Prinz, C.; Vasyutina, E.; Lohmann, G.; Schrader, A.; Romanski, S.; Hirschhäuser, C.; Mayer, P.; Frias, C.; Herling, C. D.; Hallek, M.; Schmalz, H.-G.; Prokop, A.; Mougiakakos, D.; Herling, M.; Organometallic nucleosides induce non-classical leukemic cell death that is mitochondrial-ROS dependent and facilitated by TCL1-oncogene burden. Molecular Cancer 2015, 14, 114. 
15 Selected reviews: (a) Marchetti, F. Constructing Organometallic Architectures from Aminoalkylidyne Diiron Complexes. Eur. J. Inorg. Chem. 2018, 3987-4003. (b) Mazzoni, R.; Marchetti, F.; Cingolani, A.; Zanotti, V. Bond Forming Reactions Involving Isocyanides at Diiron Complexes. Inorganics 2019, 7, 25; doi:10.3390/inorganics7030025, and references therein. c) Busetto, L.; Zanotti, V. Carbene ligands in diiron complexes. J. Organomet. Chem. 2005, 690, 5430-5440.

16 Selected references: a) Alvarez, M. A.; García, M. E.; González, R.; Ruiz, M. A. P-C and C-C Coupling Processes in the Reactions of the Phosphinidene-Bridged Complex [Fe2( $75-\mathrm{C} 5 \mathrm{H} 5) 2(\mu-\mathrm{PCy})(\mu-\mathrm{CO})(\mathrm{CO}) 2]$ with Alkynes. Organometallics 2013, 32, 4601-4611. b) Marchetti, F.; Zacchini, S.; Zanotti, V. Photochemical Alkyne Insertions into the Iron-Thiocarbonyl Bond of [Fe2(CS)(CO)3(Cp)2]. Organometallics 2016, 35, 2630-2637. c) Boni, A.; Funaioli, T.; Marchetti, F.; Pampaloni, G.; Pinzino, C.; Zacchini, S. Reversible Reductive Dimerization of Diiron $\mu$-Vinyl Complex via $\mathrm{C}-\mathrm{C}$ Coupling: Characterization and Reactivity of the Intermediate Radical Species. Organometallics 2011, 30, 4115-4122. d) Casey, C. P.; Austin, E. A. Photochemical reactions of diiron .mu.-alkenylidene complexes with hydrogen, trialkylsilanes, and diazo compounds: cleavage to alkenes, vinylsilanes and allenes. J. Am. Chem. Soc. 1988, 110, 7106-7113. e) Bursten, B. E.; McKee, S. D.; Platz, M. S. Photochemical insertion of alkynes into iron complex Cp2Fe2(CO)2(.mu.-CO)2: a mechanistic study by laser flash photolysis. J. Am. Chem. Soc. 1989, 111, 3428-3429. f) Etienne, M.; Talarmin, J.; Toupets, L. Syntheses and physicochemical properties of polycyano-substituted buta-1,3-dienylidene- and allenylidene-bridged diiron complexes. Organometallics 1992, 11, 2058-2068. g) Casey, C. P.; Niccolai, G. P. Photochemical dehydrogenation of [C5H5(CO)Fe]2(.mu.-CO)(.mu.-CHCH2CH2CH2CH3) to $\quad[\mathrm{C} 5 \mathrm{H} 5(\mathrm{CO}) \mathrm{Fe}](. \mathrm{mu} .-\mathrm{CO})(. \mathrm{mu}$.-.eta.1,.eta.3CHCH:CHCH2CH3)[FeC5H5]. Organometallics 1994, 13, 2527-2531. h) Marchetti, F.; Zacchini, S.; Zanotti, V. Carbon monoxide-isocyanide coupling promoted by acetylide addition to a diiron complex. Chem. Commun., 2015, 51, 8101-8104.

17 Agonigi, G.; Bortoluzzi, M.; Marchetti, F.; Pampaloni, G.; Zacchini, S.; Zanotti, V. Constructing Organometallic Architectures from Aminoalkylidyne Diiron Complexes. Eur. J. Inorg. Chem. 2018, 960971. 
18 (a) Albano, V. G.; Busetto, L.; Marchetti, F.; Monari, M.; Zacchini, S.; Zanotti, V. Diiron $\mu$-Vinyliminium Complexes from Acetylene Insertion into a Metal-Aminocarbyne Bond. Organometallics, 2003, 22, 13261331. (b) Ciancaleoni, G.; Zacchini, S.; Zanotti, V.; Marchetti, F. DFT Mechanistic Insights into the Alkyne Insertion Reaction Affording Diiron $\mu$-Vinyliminium Complexes and New Functionalization Pathways. Organometallics 2018, 37, 3718-3731. (c) Albano, V. G.; Busetto, L.; Marchetti, F.; Monari, M.; Zacchini, S.; Zanotti, V. Stereochemistry of the insertion of disubstituted alkynes into the metal aminocarbyne bond in diiron complexes. J. Organomet. Chem. 2004, 689, 528-538.

19 a) Marchetti, F.; Zacchini, S.; Zanotti, V. Amination of Bridging Vinyliminium Ligands in Diiron Complexes: C-N Bond Forming Reactions for Amidine-Alkylidene Species. Organometallics 2018, 37, 107-115. b) Agonigi, G.; Ciancaleoni, G.; Funaioli, T.; Zacchini, S.; Pineider, F.; Pinzino, C.; Pampaloni, G.; Zanotti, V.; Marchetti, F. Controlled Dissociation of Iron and Cyclopentadienyl from a Diiron Complex with a Bridging C3 Ligand Triggered by One-Electron Reduction. Inorg. Chem. 2018, 57, 15172-15186. (c) Albano, V. G.; Busetto, L.; Marchetti, F.; Monari, M.; Zacchini, S.; Zanotti, V. C-C bond formation by cyanide addition to dinuclear vinyliminium complexes. J. Organomet. Chem. 2006, 691, 4234-4243. (d) Mognon, L.; Richardson, S.; Agonigi, G.; Bond, T.; Marchetti, F.; Wilton-Ely, J. D. E. T. Heterotrimetallic complexes of iron and ruthenium based on vinyliminium dithiocarboxylate ligands. J. Organomet. Chem. 2019, 886, 9-12.

20 Rocco, D.; Batchelor, L. K.; Agonigi, G.; Braccini, S.; Chiellini, F.; Schoch, S.; Biver, T.; Funaioli, T.; Zacchini, S.; Biancalana, L.; Ruggeri, M.; Pampaloni, G.; Dyson, P. J.; Marchetti, F. Anticancer Potential of Diiron Vinyliminium Complexes. Chem. Eur. J. 2019, 25, 14801-14816.

21 The solubility of $\mathbf{2 a}$ in $\mathrm{D}_{2} \mathrm{O}$ at $21^{\circ} \mathrm{C}$ resulted to be $6.7 \cdot 10^{-4} \mathrm{~mol} \cdot \mathrm{L}^{-1}\left({ }^{1} \mathrm{H}\right.$ NMR analysis, $\mathrm{Me}_{2} \mathrm{SO}_{2}$ as internal standard, see ref. [20]).

22 (a) Busetto, L.; Marchetti, F.; Salmi, M.; Zacchini, S.; Zanotti, V. C-C bond formation through olefinthiocarbyne coupling in diiron complexes. J. Organomet. Chem. 2007, 692, 2245-2252. (b) Busetto, L.; Marchetti, F.; Salmi, M.; Zacchini, S.; Zanotti, V. Coupling of Allenes with $\mu$-Alkylidyne Ligands in Diiron Complexes: Synthesis of Novel Bridging Thio- and Aminobutadienylidene Complexes. Eur. J. Inorg. 
Chem. 2008, 2437-2447. (c) Dyke, A. F.; Knox, S. A. R.; Naish, P. J.; Taylor, G. E. Organic chemistry of dinuclear metal centres. Part 1. Combination of alkynes with carbon monoxide at di-iron and diruthenium centres: crystal structure of $[\mathrm{Ru} 2(\mathrm{CO})(\mu-\mathrm{CO})\{\mu-\sigma: \eta 3-\mathrm{C}(\mathrm{O}) \mathrm{C} 2 \mathrm{Ph} 2\}(\eta-\mathrm{C} 5 \mathrm{H} 5) 2]$. J. Chem. Soc. Dalton Trans. 1982, 1297-1307.

23 (a) Aime, S.; Cordero, L.; Gobetto, R.; Bordoni, S.; Busetto, L.; Zanotti, V.; Albano, V. G.; Braga, D.; Grepioni, F. Synthesis, molecular structure, crystal packing, and dynamic behaviour in the solid state of

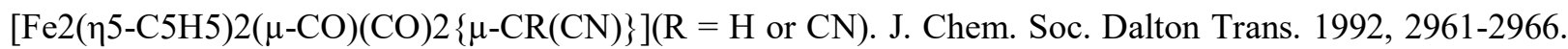
(b) Casey, C. P.; Crocker, M.; Niccolai, G. P.; Fagan, P. J.; Konings, M. S. Formation of bridging acylium and nitrilium complexes by reaction of carbon monoxide and tert-butyl isocyanide with a bridging diiron methylidyne complex. Evidence for strong electron donation from the $\mathrm{Fe} 2 \mathrm{C}$ core onto the .mu.CHC.tplbond.O and .mu.-CHC.tplbond.NR ligands. J. Am. Chem. Soc. 1988, 110, 6070-6076. (c) Orpen, A. G. Structural chemistry of binuclear metal centres. Crystal and molecular structures of the $\mu$-vinyl and $\mu$ methylcarbene complexes $[\mathrm{Fe} 2(\mathrm{CO}) 2(\mu-\mathrm{CO})(\mu-\mathrm{CHCH} 2)(\eta-\mathrm{C} 5 \mathrm{H} 5) 2][\mathrm{BF} 4]$ and $[\mathrm{Fe} 2(\mathrm{CO}) 2(\mu-\mathrm{CO})(\mu-$ CHMe)(१-C5H5)2]. J. Chem. Soc. Dalton Trans. 1983, 1427-1431.

24 F. H. Allen, O. Kennard, D. G. Watson, L. Brammer, A. G. Orpen, R. Taylor, Tables of bond lengths determined by X-ray and neutron diffraction. Part 1. Bond lengths in organic compounds. J. Chem. Soc. Perkin Trans. II 1987, S1-S19.

25 Selected references: (a) White, R. E.; Hanusa, T. P.; Kucera, B. E. Generation of Dimethylsilylene and Allylidene Holmium Complexes from Trimethylsilylated Allyl Ligands. J. Am. Chem. Soc. 2006, 128, 30, 9622-9623. (b) Connelly, N. G.; Metz, B.; Orpen, A. G.; Rieger, P. H. Synthesis, Reactions, and Molecular and Electronic Structure of the Radical Cation [Mo2( $\mu-\mathrm{C} 8 \mathrm{Me} 8)(\eta-\mathrm{C} 5 \mathrm{H} 5) 2]+$ : An Intermediate in the Redox Activation of an Alkyl C-H Bond. Organometallics 1996, 15, 729-735. (c) King, P. J.; Knox, S. A. R.; McCormick, G. J.; Orpen, A. G. Synthesis and reactivity of dimetallacyclopentenone complexes [Ru2(CO) $(\mu-\mathrm{CO})\{\mu-\mathrm{C}(\mathrm{O}) \mathrm{CR} 1 \mathrm{CR} 2\}(\eta-\mathrm{C} 5 \mathrm{H} 5) 2](\mathrm{R} 1=\mathrm{Me}$ or Ph; R2 = CO2Me). J. Chem. Soc., Dalton Trans., 2000, 2975-2982. (d) Jeffery, J. C.; Lawrence-Smith, J. G. Synthesis and reactions of coordinatively unsaturated $\mu$-3-alkylidyne clusters etc. J. Chem. Soc., Dalton Trans. 1999, 1589-1596. (e) Green, Michael; 
Orpen, A. Guy; Schaverien, Colin J.; Williams, Ian D. Synthesis, structure, and reactivity of dirhenium $\mu-$ allylidene complexes; crystal structures of $\mu-[\sigma: 1-3-\eta-3-$ methylbutenediyl]-bis(tetracarbonylrhenium)

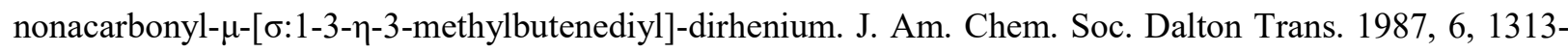
1318.

26 Albano, V. G.; Busetto, L.; Marchetti, F.; Monari, M.; Zacchini, S.; Zanotti, V. Regio- and Stereoselective Hydride Addition at $\mu$-Vinyliminium Ligands in Cationic Diiron Complexes. Organometallics 2004, 23, 3348-3354.

27 Albano, V. G.; Busetto, L.; Marchetti, F.; Monari, M.; Zacchini, S.; Zanotti, V. New bridging ligands from methylation reactions of $\mu$-vinyliminium diiron complexes. J. Organomet. Chem. 2005, 690, 4666-4676.

28 (a) Casey, C. P.; Ha, Y.; Powell, D. R. Synthesis and Reactions of Dirhenium Alkenylidene and Alkylidyne Complexes. J. Am. Chem. Soc. 1994, 116, 3424-3428. (b) Dennett, J. N. L.; Knox, S. A. R.; Charmant, J. P. H.; Gillon, A. L.; Orpen, A. G. Synthesis and reactivity of m-butadienyl diruthenium cations. Inorg. Chim. Acta 2003, 354, 29-40. (c) Peloso, R.; Carmona, E. Non-heteroatom-substituted alkylidene complexes of groups 10 and 11. Coord. Chem. Rev. 2018, 355, 116-132.

29 Murray, B. S.; Babak, M. V.; Hartinger, C. G.; Dyson, P. J. The development of RAPTA compounds for the treatment of tumors. Coord. Chem. Rev., 2016, 306, 86-114 and references therein.

30 Selected references: (a) Pettinari, R.; Marchetti, F.; Di Nicola, C.; Pettinari, C.; Cuccioloni, M.; Bonfili, L.; Eleuteri, A.-M.; Therrien, B.; Batchelor, L. K.; Dyson, P. J. Novel osmium(II)-cymene complexes containing curcumin and bisdemethoxycurcumin ligands. Inorg. Chem. Front. 2019, 6, 2448-2457. (b) Petrini, P.; Pettinari, R.; Marchetti, F.; Pettinari, C.; Therrien, B.; Galindo, A.; Scopelliti, R.; Riedel, T.; Dyson, P. J. Antitumor pentamethylcyclopentadienyl rhodium complexes of maltol and allomaltol: Synthesis, solution speciation and bioactivity. J. Inorg. Biochem. 2014, 134, 57-65.

31 Kellett, A.; Molphy, Z.; Slator, C.; McKee, V.; Farrell, N. P. Molecular methods for assessment of noncovalent metallodrug-DNA interactions. Chem. Soc. Rev., 2019, 48, 971-988.

32 Menges, F. "Spectragryph - optical spectroscopy software", Version 1.2.5, @ 2016-2017, http://www.effemm2.de/spectragryph. 
33 Fulmer, G. R.; Miller, A. J. M.; Sherden, N. H.; Gottlieb, H. E.; Nudelman, A.; Stoltz, B. M.; Bercaw, J. E.; Goldberg, K. I. NMR Chemical Shifts of Trace Impurities: Common Laboratory Solvents, Organics, and Gases in Deuterated Solvents Relevant to the Organometallic Chemist. Organometallics 2010, 29, 2176 2179.

34 Willker, W.; Leibfritz, D.; Kerssebaum, R.; Bermel, W. Gradient selection in inverse heteronuclear correlation spectroscopy. Magn. Reson. Chem., 1993, 31, 287-292.

35 Rice, N. M.; Irving, H. M. N. H.; Leonard, M. A. Nomenclature for liquid-liquid distribution (solvent extraction) (IUPAC Recommendations 1993). Pure \& Appl. Chem.1993, 65, 2373-2396.

36 a) Rundlöf, T.; Mathiasson, M.; Bekiroglu, S.; Hakkarainen, B.; Bowden, T.; Arvidsson, T. Survey and qualification of internal standards for quantification by 1H NMR spectroscopy. J. Pharm. Biomed. Anal. 2010, 52, 645-651. b) Biancalana, L.; Batchelor, L. K.; Funaioli, T.; Zacchini, S.; Bortoluzzi, M.; Pampaloni, G.; Dyson, P. J.; Marchetti, F. $\alpha$-Diimines as Versatile, Derivatizable Ligands in Ruthenium(II) p-Cymene Anticancer Complexes. Inorg. Chem. 2018, 57, 6669-6685.

37 Neese, F. Wiley Ed. Software update: the ORCA program system, version 4.0 Interdiscip. Rev. Comput. Mol. Sci., 2018, 8, e1327.

38 Becke, A. D. Density-functional thermochemistry. V. Systematic optimization of exchange-correlation functionals. J. Chem. Phys. 1997,107, 8554-8560.

39 Grimme, S.; Antony, J.; Ehrlich, S.; Krieg, H. A consistent and accurate ab initio parametrization of density functional dispersion correction (DFT-D) for the 94 elements H-Pu.. J. Chem. Phys. 2010, 132, 154104.

40 Krejčik, M.; Daněk, M.; Hartl, F. Simple construction of an infrared optically transparent thin-layer electrochemical cell: Applications to the redox reactions of ferrocene, $\mathrm{Mn} 2(\mathrm{CO}) 10$ and $\mathrm{Mn}(\mathrm{CO}) 3(3,5$-di-tbutyl-catecholate)-. J. Electroanal. Chem. 1991, 317, 179-187.

41 Sheldrick, G. M. SADABS-2008/1 - Bruker AXS Area Detector Scaling and Absorption Correction, Bruker AXS: Madison, Wisconsin, USA, 2008.

42 Sheldrick, G. M. SHELXT - Integrated space-group and crystal-structure determination. Acta Crystallogr. 2015, 71C, 3-8. 
43 Mosmann, T. Rapid colorimetric assay for cellular growth and survival: application to proliferation and cytotoxicity assays. J. Immunol. Methods 1983, 65, 55-63.

44 Rosenkranz, A. R.; Schmaldienst, S.; Stuhlmeier, K. M.; Chen, W.; Knapp, W.; Zlabinger, G. J. A microplate assay for the detection of oxidative products using 2',7'-dichlorofluorescin-diacetate. J. Immunol. Methods 1992, 156, 39-45.

45 Biver, T.; Secco, F.; Tinè, M. R.; Venturini, M.; Bencini, A.; Bianchi, A.; Giorgi, C. Intercalation of Zn(II) and $\mathrm{Cu}(\mathrm{II})$ complexes of the cyclic polyamine Neotrien into DNA: equilibria and kinetics. J. Inorg. Biochem. 2004, 98, 1531-1538.

46 Marzo, T.; Cirri, D.; Ciofi, L.; Gabbiani, C.; Feis, A.; Di Pasquale, N.; Stefanini, M.; Biver, T.; Messori, L. Synthesis, characterization and DNA interactions of [Pt3(TPymT)Cl3], the trinuclear platinum(II) complex of the TPymT ligand. J. Inorg. Biochem. 2018, 183, 101-106. 
Graphical Abstract

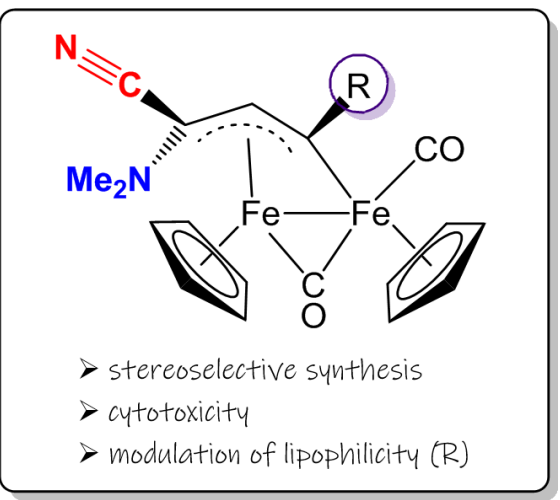

